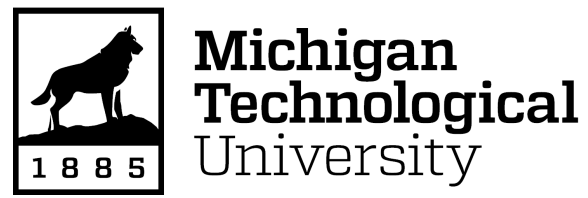

Michigan Technological University Digital Commons @ Michigan Tech

Dissertations, Master's Theses and Master's Reports

2019

\title{
GOLD MINING AND ECONOMIC PERFORMANCE IN AFRICA AND THE CASE OF GHANA
}

Josephine Amponsem

Michigan Technological University, jamponse@mtu.edu

Copyright 2019 Josephine Amponsem

\section{Recommended Citation}

Amponsem, Josephine, "GOLD MINING AND ECONOMIC PERFORMANCE IN AFRICA AND THE CASE OF GHANA", Open Access Master's Thesis, Michigan Technological University, 2019.

https://doi.org/10.37099/mtu.dc.etdr/860

Follow this and additional works at: https://digitalcommons.mtu.edu/etdr

Part of the International Business Commons 
GOLD MINING AND ECONOMIC PERFORMANCE IN AFRICA AND THE CASE OF GHANA

\author{
By \\ Josephine Amponsem
}

\begin{abstract}
A THESIS
Submitted in partial fulfillment of the requirements for the degree of MASTER OF SCIENCE

In Applied Natural Resource Economics
\end{abstract}

MICHIGAN TECHNOLOGICAL UNIVERSITY

2019

(C) 2019 Josephine Amponsem 
This thesis has been approved in partial fulfillment of the requirements for the Degree of MASTER OF SCIENCE in Applied Natural Resource Economics.

School of Business and Economics

Thesis Co-Advisor: $\quad$ Gary Campbell, $P h D$

Thesis Co-Advisor: $\quad$ Emanuel Xavier-Oliveira, PhD

Committee Member: $\quad$ Susan Amato-Henderson, PhD

School Dean: Dean L. Johnson, PhD 


\section{Table of Contents}

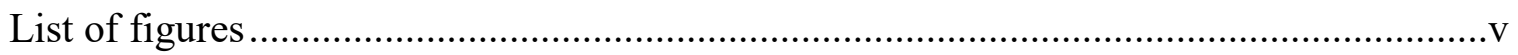

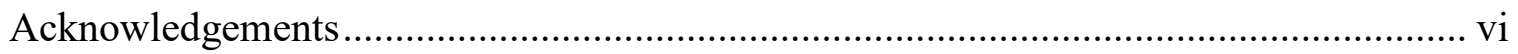

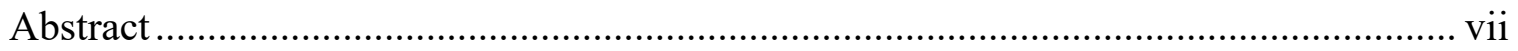

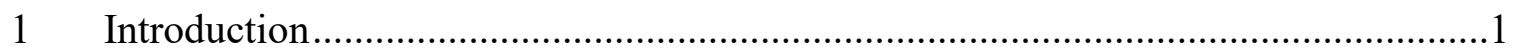

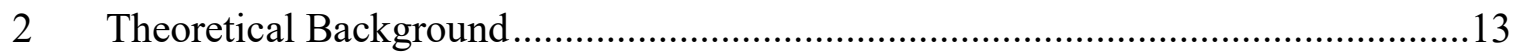

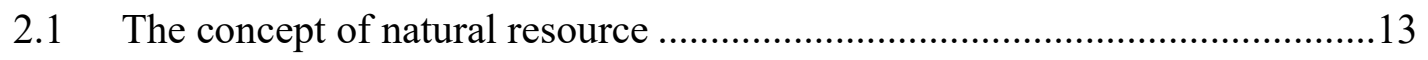

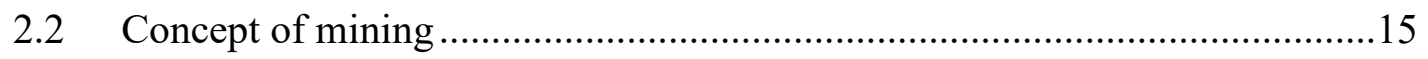

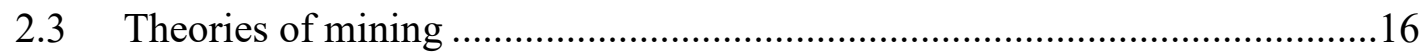

2.4 The mechanisms of resource curse (Dutch disease)......................................17

2.5 Gold production and national development …………..................................18

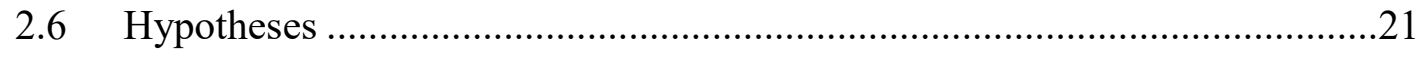

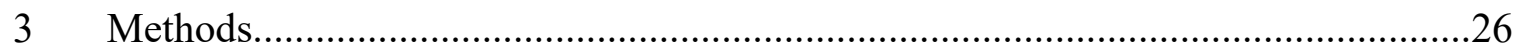

3.1 Research Approach............................................................................26

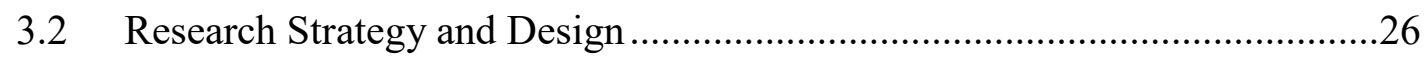

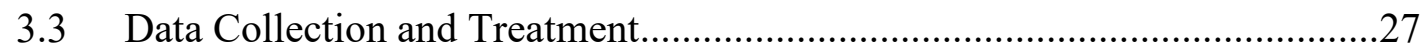

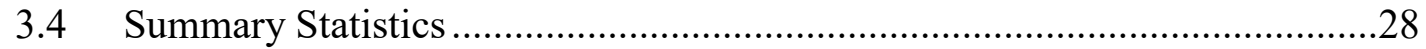

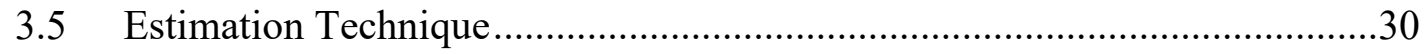

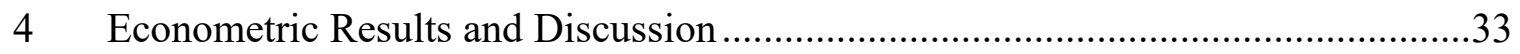

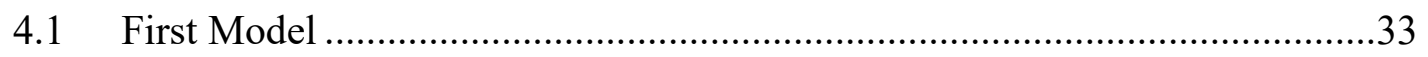

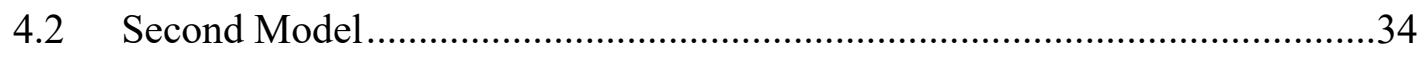

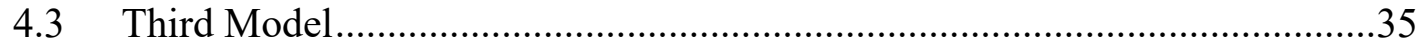

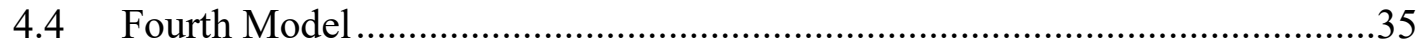

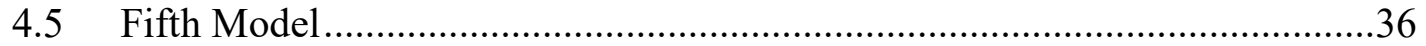

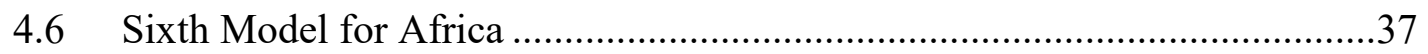


5 Conclusion and Future Research

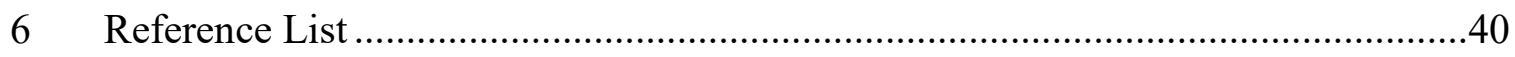

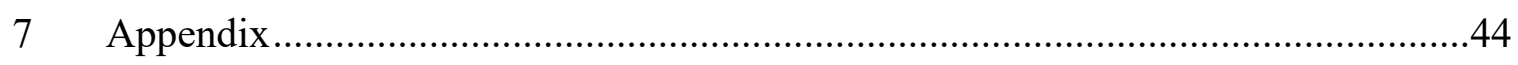

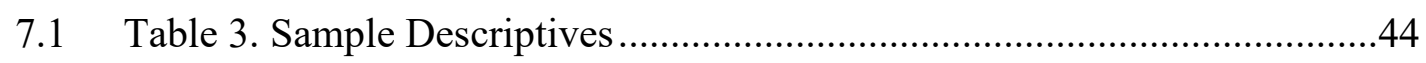

7.2 Table 6a. Regression output of GDP on independent variables For Africa ...45

7.3 Table 6b. Regression output of GDPpc on independent variables For Africa 46

7.4 Table 7a. Regression output of GDP on independent variables For Ghana...47

7.5 Table7b. Regression output of GDPpc on independent variables For Ghana 48

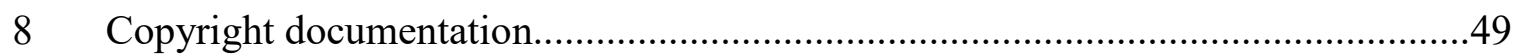




\section{List of figures}

Figure 1. Average gold produced and gold values per capita for Africa from 1999-201510

Figure 2.Gold produced for some selected African countries ......................................11

Figure 3. Gold values per capita for some selected African countries ...........................12

Figure 4 Gold production and gold values per capita for Ghana ...................................12 


\section{Acknowledgements}

I would like to express my profound appreciation to Professors Gary Campbell and Emanuel Xavier Oliveira, my advisors, without their patience, understanding and guidance I wouldn't have made it this far, most especially with my thesis.

I would also like to express my gratitude to Professor Susan Amato-Henderson, my committee member for her guidance and help during my stay on campus.

Lastly, I thank School of the business and of Economics, Michigan Technological University for the opportunities and exposure that was given me there . 


\section{Abstract}

Based on the statistical analysis of 920 observations covering forty-six countries during the 1997 to 2016 period, this study investigates the impact of goldmining on the economic performance of African nations while paying particular attention to the case of Ghana. It employs the GDP's output approach to evaluate the role that gold production may have played on GDP growth at the aggregate and per capita levels, as well as potential spillover effects across the services, industry and agriculture sectors. The empirical results for the African economies as a whole as well as for the country of Ghana in particular, suggest that gold production had a positive impact on GDP growth, both at the aggregate and per capita levels, however a more granular analysis indicates that gold mining may have buffered industrial production while concurrently augmenting output in the services sector. These potential trade-offs have important implications for policy making in African economies and the related challenge of easing an optimal allocation of resources that may foster economic growth and development. 


\section{Introduction}

The aim of every country is to build a strong and resilient economy characterised by rapid economic growth and development. Indeed, nations have been categorised based on their level of economic development. The most advanced countries are classified as developed economies and the least developed countries termed as developing economies. There are many economic performance indicators that are used to measure a country's economic progress. Such indicators include inflation, interest rates, aggregate demand, stock market index, gross domestic product (GDP), exchange rate, and unemployment rate. Countries with strong economies tend to work towards the achievement of stable and sustainable macroeconomic indicators. On the other hand, instability in these indicators may indicate economic challenges which may need to be addressed to ensure economic progression.

Yeboah (2008) asserted that in the quest to ensure sustainable economic development and positive economic performance, many countries embark on numerous activities to exploit natural resources. One such activity is mining. Thus, mining as an economic activity can contribute towards the rapid economic development of countries endowed with such natural resources (Yeboah, 2008). Adjei, et al (2012) indicated that mining turns out materials such as bauxite, diamonds, coal, iron, lead, precious metals, limestone, phosphate, nickel, gravels, tin, salt, molybdenum and uranium. Mining in a broader sense can cover the extraction of natural gas, petroleum and even water. Mining brings foreign exchange investment and employment opportunities, and other supplementary benefits to areas endowed with natural resources (Adjei, et al, 2012). Reserves of mineral wealth have attracted foreign direct investment to developing countries especially in Sub-Saharan Africa (Kováŕová, 2015).

Mining is one of the oldest industries to have ever developed in Africa as a whole and Ghana in particular. Africa has always been known to be the birthplace of mankind, and for centuries it has supplied and satisfied the needs of nations. It has stocks of energy and abundance of natural resources that has pushed many nations that have fed on them to prosperity and greatness. There are many countries on the continent engaged in gold 
mining to varying degrees, but Ghana and South Africa are the major gold mining countries in the continent and the history of mining cannot be told more precisely without tracing the history of these two major gold mining giants. These two countries have traded with the Europeans as early as 1300 s, and gold trade was one of the many attractions to Africa.

One major tribe that was known to trade in gold and prospered on gold trading was the Mapungubwe Kingdom. They were mostly located in present day Zimbabwe, South Africa and Botswana. The tribe traded with Europeans, Persians, as well as the Chinese in the Port City of KilwaKisiwani for salt and porcelain (www. Study.com). The Europeans sought to control raw materials in the region, and this was the major driver for colonization in the early part of the $19^{\text {th }}$ century; between 1870 and 1929 .

During the pre-colonial era, gold mining activities were incorporated into the economy of the indigenes and this was drastically transformed into a system expedient for the colonizers where foreign owned corporations controlled and owned majority of companies in the gold mining sector. The British, Belgians and Portuguese were the first key players in the game and were later joined by the French. Africans were mainly consigned to low skill and hazardous works.

This structure has transcended into the current growth model of the mining sector in most African countries especially those in the Sub-Sahara. The growth model constitutes policies that favor and are biased towards large scale foreign businesses which are export driven. (Hilson 2018). The World Bank and International Monetary Fund advocate for the host countries to make policies that are amenable to these large-scale foreign companies as they are the 'catapults' to economic growth. These assertions have proven to be false as these policies as implemented have only created 'enclaves'. The majority of the mines operate independently from the rest of the economy; gold products are exported and refined outside the host countries. One contributing factor to this issue is due to the fact that fees, permit acquisition and licenses are lax for foreign investors. Hilson ,2018, suggests that there should be policy changes biased towards small scale miners where licenses and permits must be expedited for easy access to the artisanal miners. 
In the pre-colonial era, miners were restricted by their operating surroundings and negotiations were complex and difficult with local folks. The reverse is now the case. Foreign companies are now backed by the World Bank and major transnational financial institutions and political powers who have also manipulated the African countries through multifarious sector modification processes with the subtle aim to aid foreign investors. Even gold extracted in Africa is refined in countries outside of the region. (Hilson, 2018). Hilson suggests for the African host countries to enjoy 'forward linkages', the sector must be structured to cater for the needs of artisanal and small-scale miners. In the current situation foreign mine corporations fill all vacant positions for support services created by the explosion in the sector. In Ghana, for instance, a 'mine support license' for businesses interested in mining costs minimal fee of U $\$ 250$, renewed yearly whereas per capita was GDP in 2017 was $\$ 2046.1$

Ghanaians were mining gold, iron, and other commodities long before the dawn of colonisation. Ghana is thus seen as a very resource rich country endowed with gold, manganese, diamond, bauxite, oil and others. The mining sector is therefore considered as a vital segment of Ghana's economy and has played a substantial part in the socioeconomic development agenda of the country since the colonial era. According to the Bank of Ghana (2003), the mining industry contributed between $8 \%$ and $17 \%$ of total domestic collection by the Ghana Revenue Authority between 1990 and 2002. During the period, the mining companies paid $\phi 619$ billion in royalties and $\phi 170$ billion in taxes to the government. Traditionally, the contribution of the mining sector to Ghana's gross foreign exchange is matched only by the cocoa industry (Akabzaa and Darimani, 2001). The importance of the mining sector has led to many intensive policy modifications and restructuring since the era of the 'structural adjustment programme' in the 1980s. The reforms have brought within its wake increased investments, new mines, and new minerals. "The sector, therefore, presents strong potential to generate substantial revenue and employment enough to provide more visible economic benefits to the country and improved livelihood for the population" (Akabzaa 2007). 
In spite of the importance of the mining sector towards the economic development agenda of Ghana, many have been sceptical about the positive impact of the sector on the economic performance indicators of the country given potential crowding out effects on other economic sectors.

The history of the current state of gold mining in Ghana can be traced back to the precolonial and the post-colonial eras. In precolonial times, Ghana was a major source of gold that was transported to Europe through the trans-Saharan trade courses. Portuguese sailors were the first Europeans to locate and to control gold, and mining was mostly alluvial without any sophisticated equipment and underground mining only started around 1860.

Thomas Hughes a British national imported heavy machinery to begin mining in the western areas of modern Ghana. Two Fante men from the coastal parts of Ghana, Joseph Ellis and Joseph Biney, unearthed the richest deposit in Obuasi and sold the privileges to the reserve on the cheap to E. A. Cade, a Briton who was the founder of Ashanti Goldfields Corporation (AGC) in 1897, and the foremost gold mining company in Ghana. During the Colonial Era, The British government regulated the sector to safeguard the earnings of European corporations and gold possession was illegal. To bring power back to the people, after the country gained independence in 1957, foreign influence of the sector was restricted. The sector experienced decline in the late 1960s until the 1980s and in the 1990s the government liberalized and tried to regulate the industry and create foundations for sustainable growth. The indigenes were able to start mining again and this brought up artisanal and small-scale mining. In 2019, there are around twenty-three legitimate big mining companies in Ghana, employing approximately 526,000, "(about 20,000 in the large-scale subsector, 500,000 in the small-scale gold, diamond and quarry mining sub-sectors and, roughly 6,000 in mine support services", (Wikipedia Free Encyclopaedia, 2019). The major mining ranked by gold production in the year 2017 were Goldfields Tarkwa mines, Newmont Akyem mines and Newmont Ahafo mines. All these are foreign owned multinational companies. The former mining giant and the first gold 
mining company in Ghana has been put on care and maintenance since 2014 and at the time of this report it hadn't resumed operations.

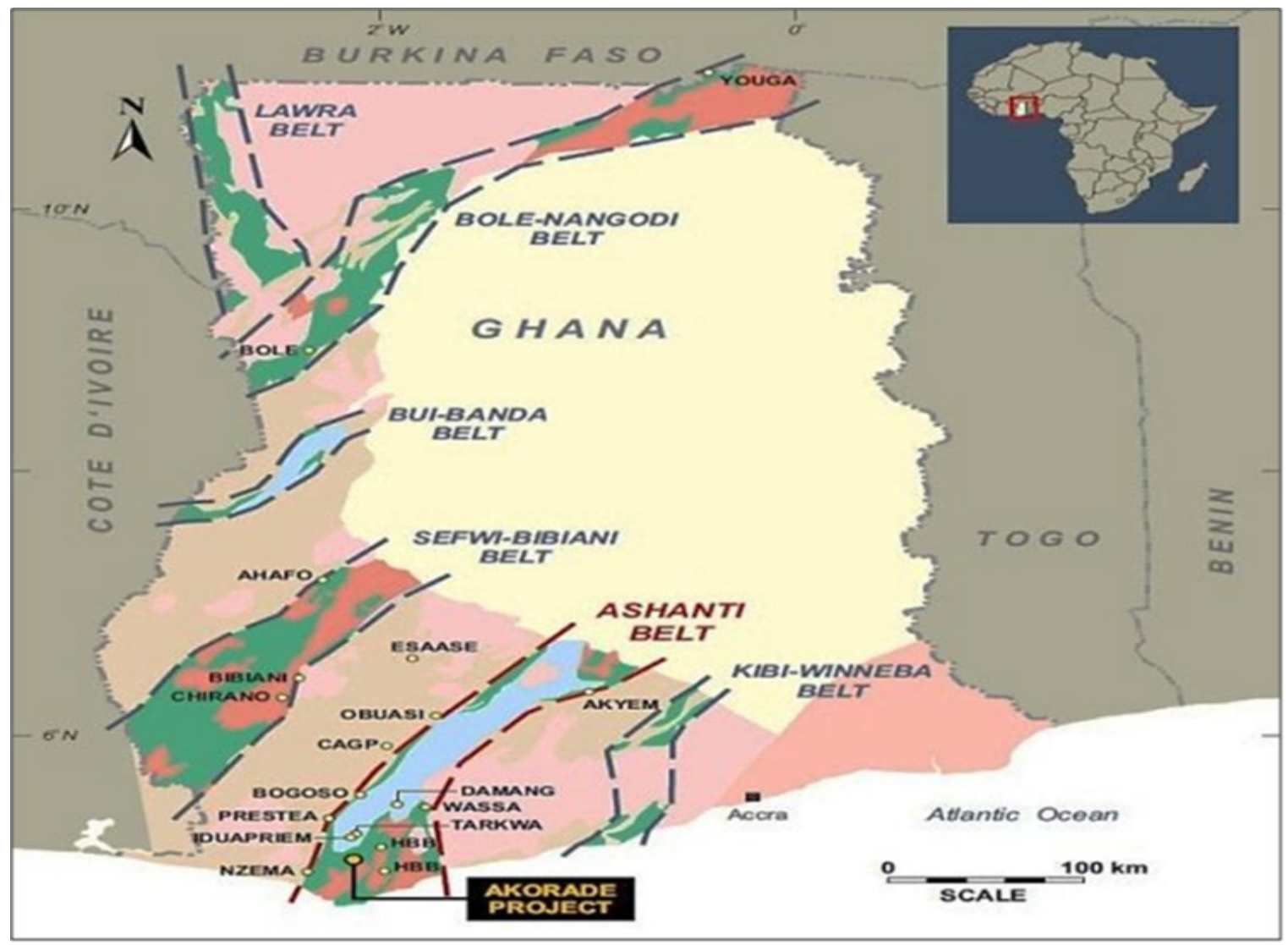

Source: http://uoguelph.ca

Minerals Deposit (Belts) Map of Ghana.Image source: Google maps, available at https://www.google.com/search?q=Map+Regions+with+gold+deposits+in+Ghana. 


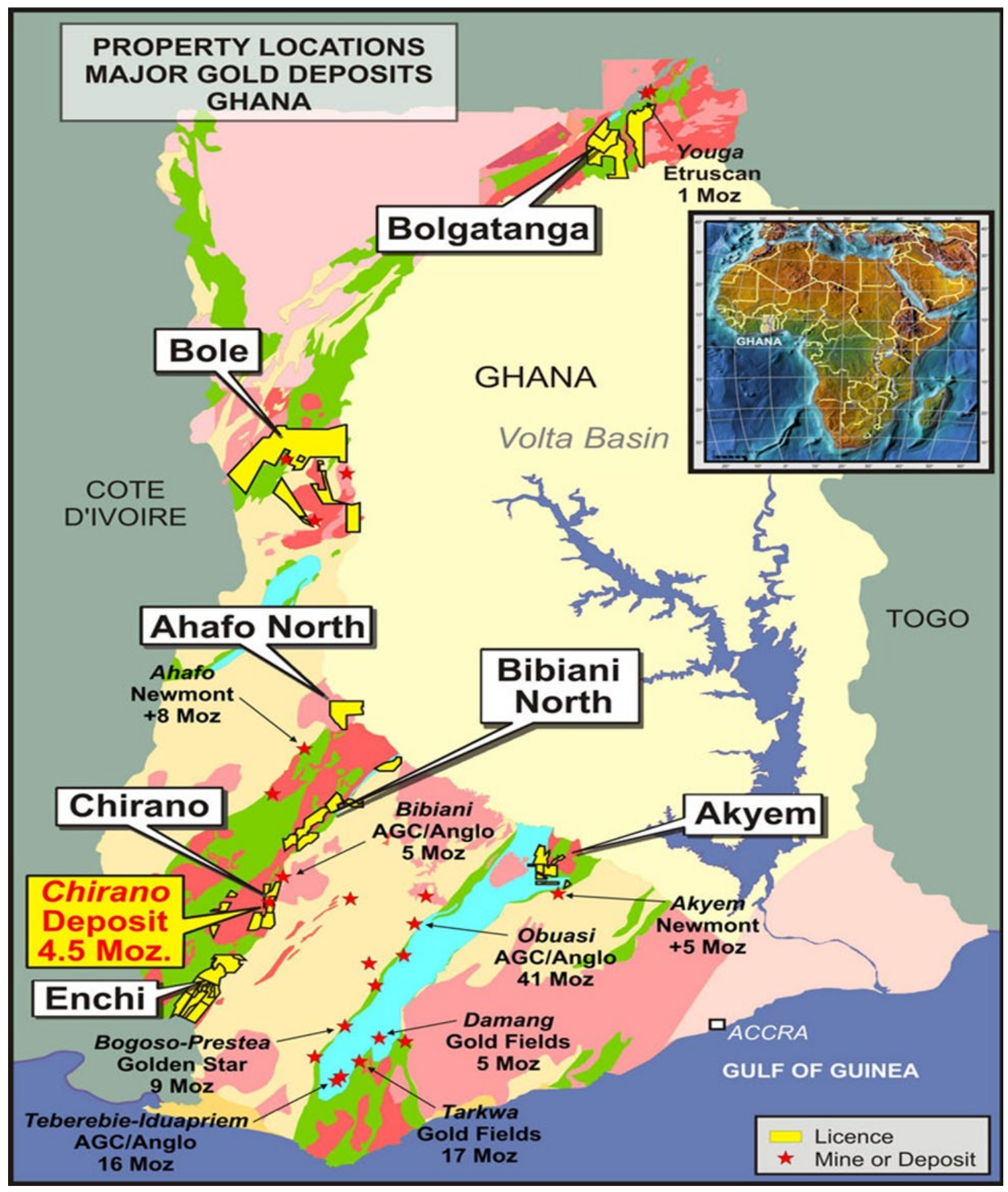

Map Regions with gold deposits in Ghana. Image source: Google maps available at https://www.google.com/search?q=Map+Regions+with+gold+deposits+in+Ghana 
Mercury, the main chemical which is used in dissolving gold by the small scale and artisanal miners causes serious health problems. A UN Industrial Organization established that the majority of rural dwellers sampled, including non-miners, revealed unsafe amounts of mercury in their bodies as well as high concentration levels in fish.

Galamsey, the local term for small scale mining, leads to reduction in the cultivation of economic plants like cocoa and cashew, which are a major source of foreign exchange. Some of the most serious environmental impacts include: mass deforestation from vicious prospecting and mining; mercury contamination of natural resources; small-scale acid mine drainage (AMD) and associated heavy and hazardous metals leaching; mass soil erosion; small-scale habitat destruction; and "pot holed" landscapes ensuing from incomplete mine closure is a major cause of malaria, the number one killer disease in Ghana as discussed by Hilson (2002).

Around 2009, Ghana was one of the major gold producers in the world, second behind South Africa and the ninth in the world, producing about 3.8\% of total worldwide gold, moving up from the $2.6 \%$ of total production in 2004. Revenues obtained from production surged considerably in the past decade. Ghana in 2018 was the tenth largest producer of gold and second in Africa after South Africa. But do these positive attributes translate into economic growth? Despite these positive attributes?

The 'resource curse'has been a compelling issue for the resource endowed countries across the globe but it is usually prevalent in the developing countries. Many reasons have been ascribed to this phenomenon. But the unsatisfactory and unacceptable fiscal revenues from the mining, oil and gas areas can be attributed to the kind of 'growth model' existing in these industries. The mining sector in the developing countries are dominated by foreign large-scale export driven organizations who pump large sums of foreign funds into the sector resulting in the increase in multinational gold mining organizations in the host country (Hilson, 2017). This eventually culminate in 'capital flight'; the local communities and the country at large do not benefit from the mining activities as mining companies do 
not invest in the countries they mine and improve the skills base and livelihood of the indigenes (Hilson, 2017).

Guyana, which according to Hilson (2017), is a 'success case' among a few countries that have had a different approach to the growth of the mining sector. This industry is predominantly made of the local small-scale mining companies and this has considerably promoted its economic development path but then, Hilson asks whether it has been able to rid itself of the drawbacks of the 'resource curse'.

According to Hilson (2017) one characteristic of gold enriched countries like Papua New Guinea, Ghana,the Philippines and Peru, and their mining industryis that the main focus on mining is gold, and the industry concentrates on exports of its products and this has not supported meaningful socio-economic development for these countries.

He further suggests that the incessant global demand for gold for jewellery and for trading in commodity markets has driven gold mining universally. In addition, donor nations have advised developing countries to increase the exposure of the mining sector to foreign investment, expand the mining industry to promote and advance their economies in general. The foreign mining companies enjoy tax breaks and other enticements from the host countries over several years, the mining sector expands and yet the fiscal revenues obtained dwindles.

Bloch and Owusu (2012), asserted that gold mining usually is perceived 'as having an 'enclave status' disconnected and isolated from the rest of the economy,' thus having no significant or appreciable impact on the economy especially since the gold mining areas are predominantly owned by the private sector with the government having some little to no share in these companies.

In analyzing the impact of Ghana's mining sector since the country's independence, Hilson and Hilson (2017) comment that the country's vibrant sector which is predominantly large-scale mining has yet to translate to economic development. Hilson, just like Bloch and Owusu, attributed this problem to the 'enclavity' concept which albeit 
produces large quantities of gold, operated in comparative seclusion and are thus detached from the rest of the economy. He cited a definition of 'abjectivity' in Fergusson (1999), he witnessed in Zambia, where the communities in the mining localities were 'thrown aside, expelled or discarded,'. Bush (2010), in Hilson and Hilson (2017), defines objectivity as 'consequences of the way modernity failed to deliver the promise of (...) moving forward or joining up with the world' (Fergusson, 1999, 254) in Hirschman (1958) in Hilson and Hilson (2017), entreats developing countries to develop 'linkages' to catalyze economic development.

Ghana, after independence in1957, tried to nationalize its mining sector. Hilson suggests that the populace, after independence were not technically skilled to take over the mining sector leading to creation of the enclaves which ended in the collapse of the mining sector in the 1960s and 1970s and resulted in economic regression in the 1980s (The Economist 23 September, 1989) in Hilson and Hilson (2017).

\section{0s -Present}

Although, Ghana cannot be termed as a 'rentier state' (Malidavy, 1970) in Hilson (2017) like Nigeria and Angola, who are endowed with oil and gas, subsequent presidents followed Nkrumah, the first president of Ghana's legacy and ideologies of economic policy and under a recommended Economic Reform Program by the world bank which favored tax breaks, and other incentives for the large-scale sector and while eliminating import duties for certain 'goods' imported by the mining companies, the mining sector continued to deteriorate. Also, prominence was not placed on the institutions that monitor and regulate the revenue collection.

The graphs below display gold produced in ounces and in dollar values for Ghana and for some selected countries in Africa in aggregate and per capita levels. 
The figures 1 to 4 below show recent data on gold production and value for Africa as a whole, then a few selected countries, and lastly Ghana. Figure 1 shows gold produced in Africa from 1997 to 2015 in aggregate and per capita levels. Figure 2 shows gold produced in some selected African countries namely Ghana, Cote d'voire, South Africa, Nigeria, Burkina Faso Guinea and Mali from 1999 to 2015 while figure 3 displays per capita gold produced for the same countries. Figure 4 shows gold produced in Ghana in ounces and per capita from 1997 to 2015.

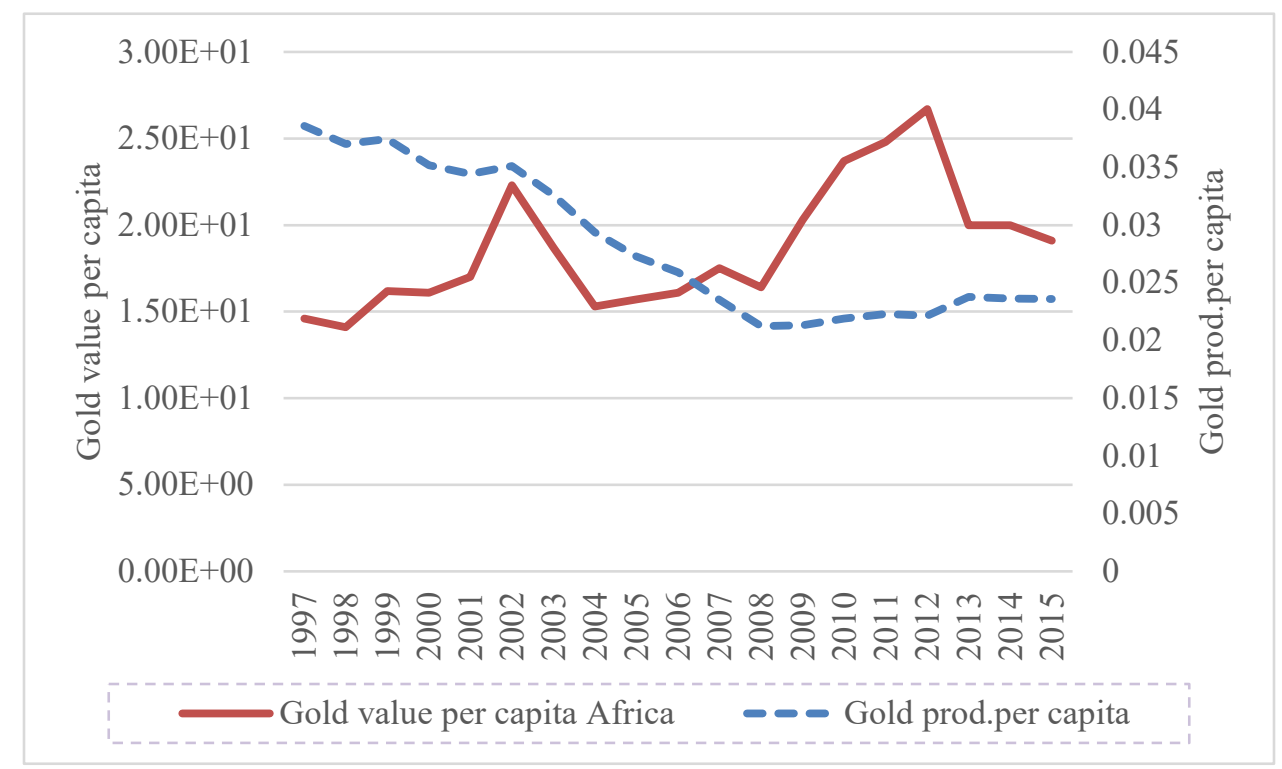

Figure 1. Average gold produced and gold values per capita for Africa from 1999-2015 


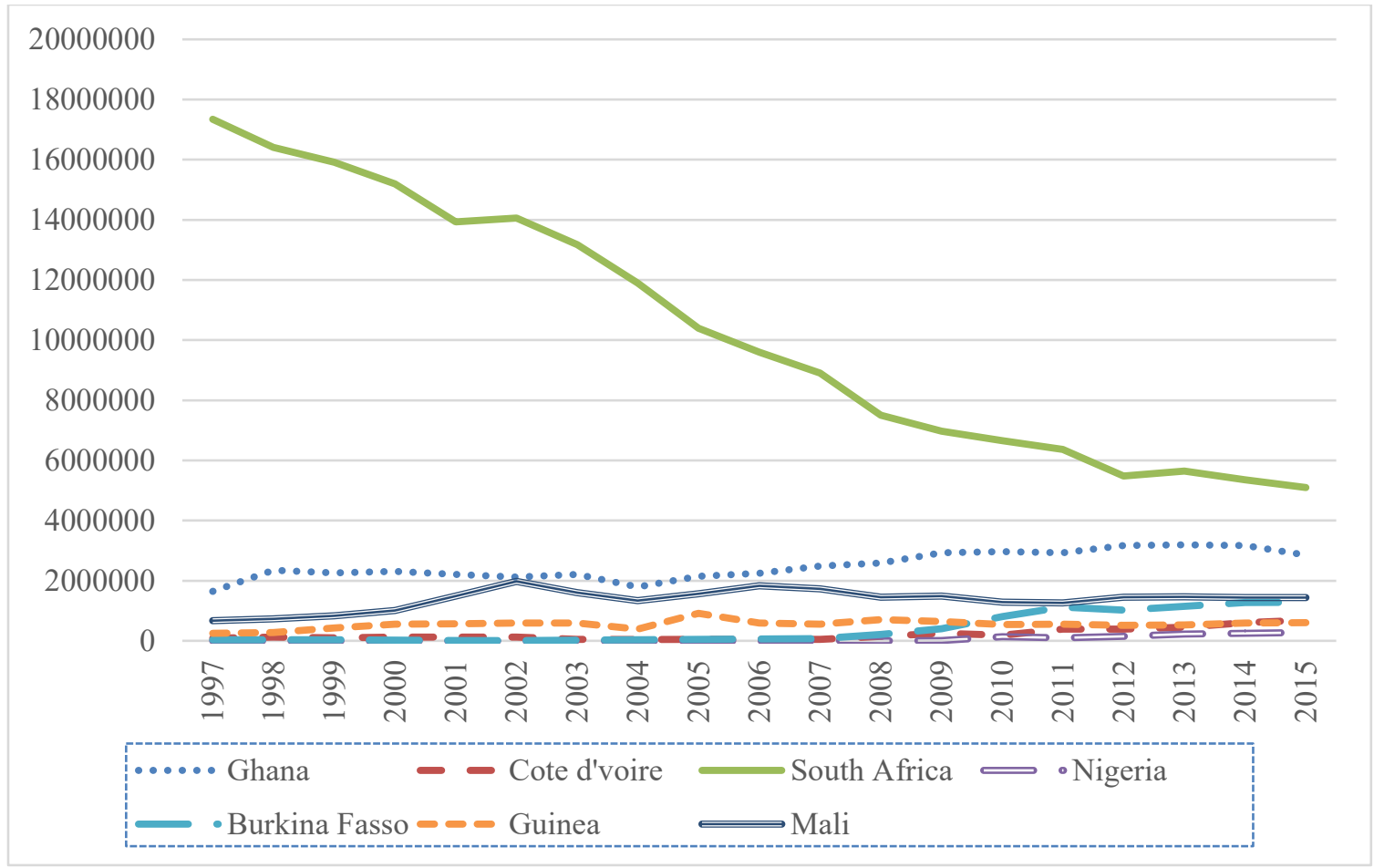

Figure 2.Gold produced for some selected African countries 


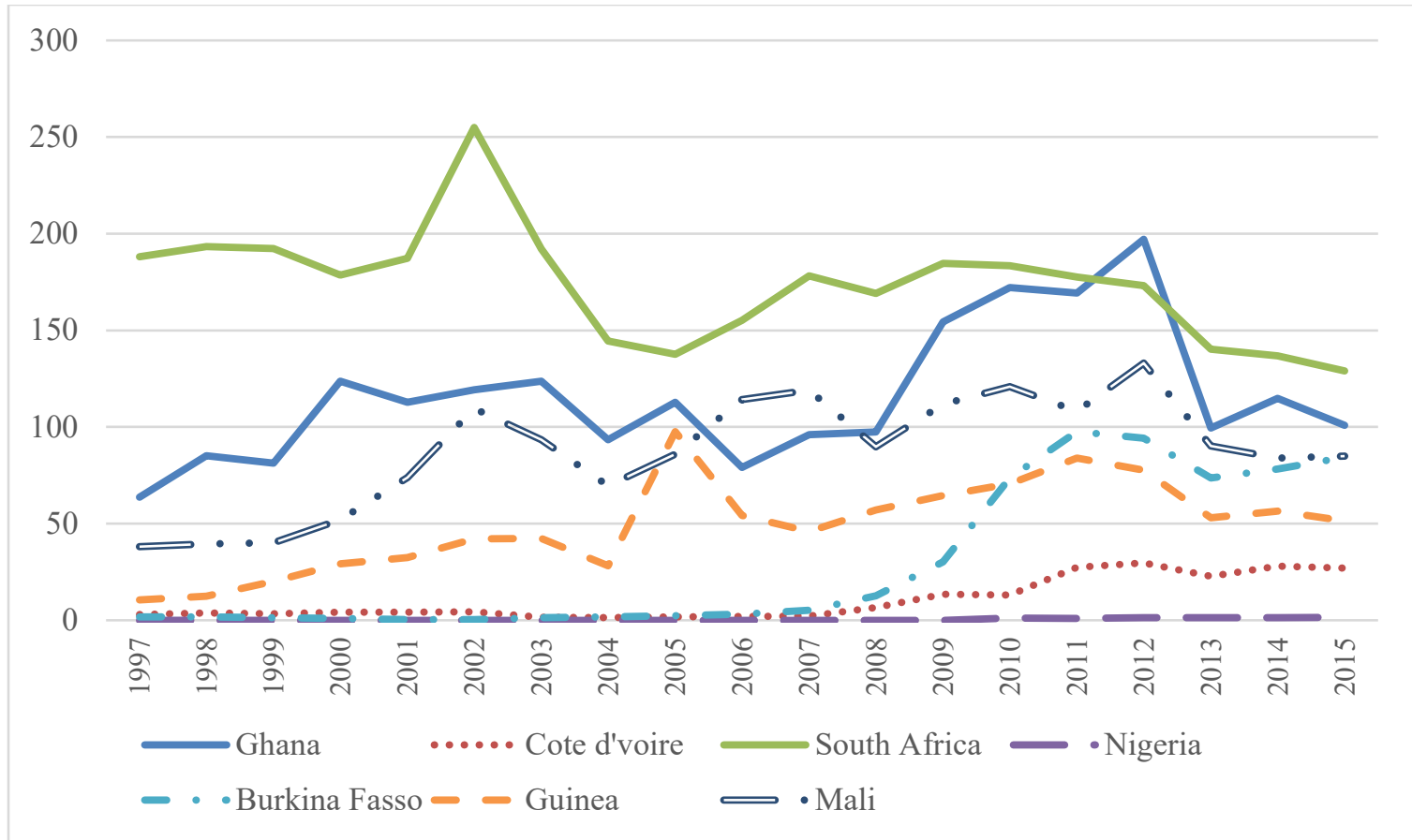

Figure 3. Gold values per capita for some selected African countries

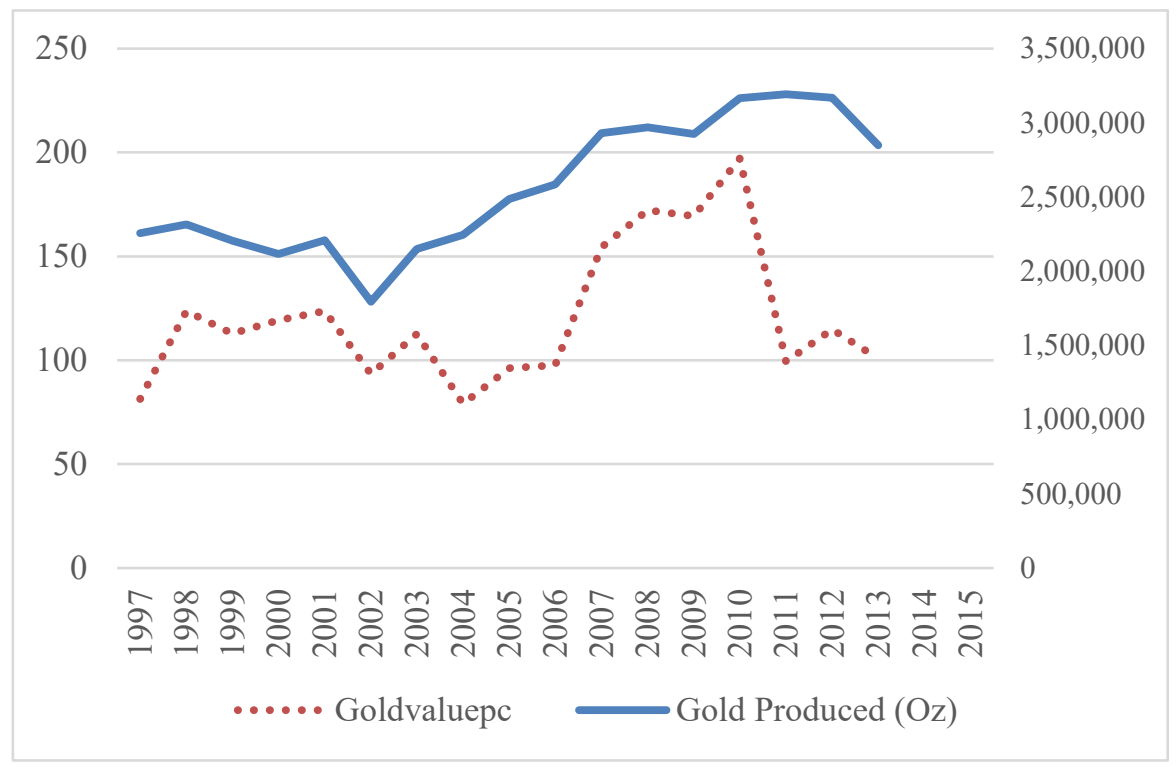

Figure 4 Gold production and gold values per capita for Ghana 


\section{Theoretical Background}

The theoretical literature of the study has been divided into six sections. The first section focuses on the concept of natural resource. The second section highlights on the notion of mining. The third and fourth sub-sections assess some theories that underpins mining and the mechanisms of resource curse particularly the Dutch disease respectively. The last two sections explain the concept of economic performance with regards to gold production and national development, assessing and discussing and reviewing literature on the subject matter. The essence of the literature review is to provide both theoretical and empirical background to the study. The last section discusses hypothesis development based on the objective of the study that are to be tested. Literature supporting the hypothesis are also reviewed

\subsection{The concept of natural resource}

The term natural resource has been variously defined by different authors and international institutions (Hlavova, 2015). Soubbotina (2004) describes natural resources as "all gifts of nature -air, land, water, forests, wildlife, topsoil, minerals- used by people for production or for direct consumption". The definition as suggested by Soubbotina (2004) sets two main parameters of natural resources. The first parameter is that; natural resources must be a gift of nature. This presupposes that anything man-made cannot be described as natural resources. However, this does not mean that anything done by man that seeks to renew, recreate or produce more of an existing natural resource does not constitute a natural resource. For example, the construction of water pond or dam even though may constitute man-made activity, the water in the dam constitutes natural resources. The second parameter is that; natural resources must be useful for production or consumption. This parameter suggests that if a gift of nature has no immediate usage for production or consumption, then it is not a natural resource. However, the challenge is that a gift of nature may not has an immediate usage in terms of furthering production or consumption but may be useful in future. 
Hlavova (2015) however gave a definition of natural resources and eliminated the phrase gift of nature. According to Hlavova (2015), natural resource is an "asset or material that constitutes the natural capital of a nation. Natural resources require application of capital and human resources (mental or physical labor) to be exploited (extracted, processed, refined) for the realization of their economic value." Hlavova (2015) definition introduces two major concepts into the natural resource definition game. The first issue is that for resource to be a natural resource, it must be a natural capital of a nation. Even though, Hlavova (2015) did not expatiates on what defines a natural capital of a nation, per the words used in the definition, it can be argued that the phrase "natural capital of a nation" means it must be capable of being a major source of revenue for the state. The second issue is that natural resources are exploited (extracted, processed, refined). This means that resources that are harvested like food may not constitute natural resources even though Perman, et al (2003) defines natural resources to include renewal stock resources such as food. However, minerals such as gold, oil, and gas are natural resources according to Hlavova (2015).

Per the purpose of this study, defining natural resource is critical. This claim is based on the fact that not properly defining what constitute natural resources may lead to its miscalculation. For example, using Perman, et al (2003) definition of natural resources may mean that agricultural produce must be included in its calculation. However, since the study is interested in the impact of mining on the economic performance of Ghana, Hlavova (2015) definition of natural resource was adopted. The justification of this decision is grounded in the fact that by using Hlavova definition, resources such as agricultural produce will be excluded in the determination of natural resources thereby limiting the study to mineral resource. 


\subsection{Concept of mining}

Acheampong (2004) asserted that mining is the extraction of natural resources from the crust of the earth for the usage of mankind. This definition suggests that mining constitutes earthly activities. In other words, the harvesting or extracting of atmospheric substances or heavenly bodies do not constitute mining. This definition puts mining in a narrow context. Yeboah (2008) cited a definition from Encarta encyclopaedia which states that "mining is the selective recovery of minerals and materials, other than recently formed organic materials from the crust of the earth". According to Wikipedia (2019), mining encompasses the removal of valuable mineral deposits or other geological materials from the earth, typically from a vein, ore body, or coal seam. Wikipedia (2019) cited resources that are extracted from mining to include iron, oil, bauxite, lead, coal, gas, limestone, diamonds, salt, nickel, molybdenum, uranium, and tin.

The term mining has also been used to refer to the industry, activity and the profession concerned with the abstraction of mineral deposits. Minerals have been divided into three (3) main groupings. The first category is the metallic ores. The metallic ores are the ferrous metals (example iron, manganese, molybdenum and tungsten), the base metals (such as zinc, copper, lead and tin), the precious metals (for instance the platinum group metals, gold, and silver), and the radioactive minerals (thorium, uranium, and radium). The second type is the Non-metallic minerals (known as industrial minerals). The non-metallic minerals are the non-fuel mineral ores that are not allied with metals production. They comprise of, phosphate, potash, sand, trona, gravel, halite, limestone, sulphur, and many others. The last type is Fossil fuels (also known as mineral fuels). These are the organic mineral substances that are usually exploited as fuels, such as coal, coalbed methane, natural gas, gilsonite, petroleum, and tar sands (Anonymous, undated).

Modern mining life cycle involves five stages. These are prospecting, exploration, development, exploitation, and reclamation. Traditional exploitation method involves two groups namely surface or underground mining. Surface mining embraces mechanical excavation methods such as open pit and open cast (strip mining), and aqueous methods such as placer and solution mining. Underground mining is generally grouped into three 
methods. These are unsupported, supported, and caving methods (Mensah, et al, 2015). For the purpose of this study, mining shall refer to the extraction of metallic ores, non-metallic minerals, and Fossil fuels whether through surface or underground mining

\subsection{Theories of mining}

Mining is critical to the economic performance of many countries (Walser, undated). However, scholars disagree on the relationship between mining and economic development and performance. Davis and Tilton (2002) asserted that there are two main theories that underpins the issue of mining and economic performance or development. The first school of thought is the traditional view of mining. The traditional theory asserts that there is a positive relationship between mining and economic performance of mining countries. This theory rest on the concept of production function (Davis and Tilton, 2002). The traditional view postulates that the more capital a country has, the greater its output and per capita income (ceteris paribus).

The traditional view argues that mineral wealth if mined forms part of a country's stock of capital. "Generally, the more capital a country possesses, the greater the output and hence higher per capita income". The traditional view asserts that mineral deposits left unmined remain unproductive. Thus, mining helps to convert "mineral resources into a form of capital that contributes to a nation's output". The theory depicts that mineral resources extracted could be consumed or invested. If consumed, it will raise the current welfare and if invested, it will raise future welfare resulting in economic growth. The traditional view assumes that funds will be invested wisely. Poor investment "may provide little or no future benefit to the country". In that situation, the problem is not mining but government and its ancillary institutions. Mining provides opportunity for a country.

The second school of thought is called "the new view". Davis and Tilton (2002) indicated that per the new view, "greater dependence on mining is associated with poorer economic growth, and so directly contradict the traditional view of mining”. Simply put, 
accumulated empirical evidences suggest "that mining and economic development are is negatively related" (Davis and Tilton, 2002). Aunty (1993) argued that nations that depend on natural resources face "resource curses". This curse "refers to an inverse correlation between natural resource dependence and economic growth" (Badeeb, et al, 2017). Badeeb, et al (2017) argues that, the sheer weight of different "studies finding poor growth records of most countries with high resource dependence" makes the resource curse theory valid. However, the lack of consensus in literature in relation to whether resource dependence is a blessing or curse makes further studies on the subject matter inevitable. This means that this study was conducted to find empirical evidences that will accept or deny the two theories. However, for the purpose of stating the research hypothesis, the traditional view of mining was adopted. In other words, the hypotheses were stated in a positive sense.

\subsection{The mechanisms of resource curse (Dutch disease)}

Badeeb, et al (2017) argued that it is not enough to show that there is a negative relationship between resource dependence and poor economic performance but to investigate the mechanisms that cause this negative association. Badeeb, et al (2017) stated that these mechanisms could be grouped into economic and political explanations. The economic explanations for the resource curse include "Dutch disease phenomenon, the volatility of commodity prices, failures of economic policy, and the neglect of education. Politically, the main mechanisms are traced to rent seeking, weak institutions and corruption" (Badeeb, et al, 2017). A careful assessment of these factors may show that failure of economic policy, neglect of education, rent seeking, weak institutions and corruption are factors which are not confined to resource dependence or mining countries but are endemic in most developing nations. These factors are, therefore, not considered as explaining the resource curse for the purpose of this study. On the other hand, even though volatility of commodity prices is a possible reason for the resource curse, it does not fit the goals of this study. This study will therefore test the Dutch disease as a possible mechanism for the resource curse. 
Badeeb, et al (2017) asserted that the Dutch disease may also be caused by a shift of labour and other domestic inputs from the "non-resource sectors such as manufacturing and agriculture" leading to high input prices. Due to the inability of the non-resource sectors to compete with the resource sector, it causes the non-resource sectors to contract out. This adversative effect on non-resource areas is called the resource "pull effect" (Humphreys et al., 2007). The "spending" and "pull" "effects of growth in resource output could then partially or more than partially crowd out non-resource output, and growth overall" (Badeeb et al, 2017).

Lawer, et al (2017) have argued that Ghana is not a primary example of resource curse country due to political factors. The country has performed well relative to other subSaharan African countries in terms of democratic indicators and there are those who believe that the country could avoid the resource curse mantra (Green, 2008). There is therefore the need to investigate how gold mining has affected the GDP of Ghana in order to establish whether the country is resource curseddue to economic reasons. In other words, if Ghana is resource cursed, then it is expected that there will be adverse relationships between gold mining and the selected macroeconomic indicators.

\subsection{Gold production and national development}

Khramov and Lee (2012) have argued that a lot of people do not understand basic economy theory and are confused by the immense number of different economic statistics reported in the media in spite of the current improvements in the science of economics. In view of this, many citizens find it difficult to compare and contrast their country's economic performance. The result is that critical economic performance information become lost on the public. Economic experts in assessing the performance of political economy are sometimes hindered by appropriate tools that could be used to assess the macroeconomic performance of a country. The result is the difficulty in answering many questions such as how a country's economy is performing in comparison with others (Khramov and Lee, 2012). 
There are many macroeconomic indicators that could be used to assess the economic performance of a country. Olsen (2009) stated that economic indicators are quantitative analytical tools used to measure the economic health of an economy. they give a bird eye view of the economic performances of certain sectors at a certain point in time (Baumohl, 2008). Stiglitz (2017) alerted that we need good econometrics to monitor and diagnose what is going on - what is happening to well-being in all of its dimensions, and how different groups within society are being impacted; assess the source of the changes; and motivate civic action. Stiglitz (2017) continued that "without measures of economic aggregates like GDP, policymakers would be adrift in a sea of unorganized data. The GDP and related data are like beacons that help policymakers steer the economy toward the key economic objectives".

Olsen (2009) indicated that good examples of economic performance indicators include the consumer price index which measures inflation, gross domestic product (GDP), interest rate (which measures cost of borrowing), exchange rate, stock market index, unemployment rate, aggregate demand, money supply, and budget deficit. Although the number of economic indicators is myriad, their interpretation is also not easy. Some indicators are erroneous and need to be modified, whiles others have lag between when they are released and when needed, making the information released therein almost useless in real time. In addition, some indicators contradict each other making it difficult to draw a conclusion as to the health of an economy. The Conference Board (2001) states; "there is no single time series that fully qualifies as an ideal cyclical indicator", and that in order to fully appreciate the performance of an economy, there is the need to select "broad range of different indicators to give a simple all-round understanding of the state of the economy" (Olsen, 2009).

Stiglitz, et al (2008) divided economic indicators into three main groupings. These are: a) "leading indicators- the growth of the money supply, stock prices, slope of the yield curve, and the exchange rate; b) coincident indicators- reflect the intensity of economic activity. Employment, production, housing activity, retail sales, car sales, and purchasing manager indexes are the most useful ones. (They are reported in the news as they happen 
and they mirror current business activity) and c) lagging indicators- are the most crucial gauges. The significant ones are short-term interest rates, bond yields, inflation at the producer and at the consumer level, and growth in commodities". Stiglitz, et al (2008) asserted that "GDP is the most widely-used measure of economic activity and that it mainly measures market production expressed in money units".

This paper seeks to examine the relationship between gold productions specifically, and GDP in Ghana, while examining the impact of the other sectors of the economy. These results (relationships) are corroborated by looking at the other forty-five African countries excluding Djibouti, Equatorial Guinea, Eritrea, South Sudan Seychelles, Togo and Libya due to lack of exhaustive data on gold produced.

In order to achieve the general objective of the study, the following specific objectives were pursued: evaluate the correlation between mining and GDP growth and whether this relationship is significant, and establish the relationship of the other sectors of the economy with GDP in Ghana and evaluate the correlation between GDP and mining in Africa.

The study in particular focuses on gold mining, as a contributor to GPD in comparison with industry, services and the agriculture sector.

Gross domestic product (GDP) is the total value of output produced in a given time period and also measures the output of final goods and services domestically within that specified period regardless of who owns the factors of production. In effect, gross domestic product is the "market value of all final goods and services produced within a country in a given period of time,"(Thoughtco,2019). Using the product approach, GDP measures and sums up the "quantities of all final goods and services produced in an economy within a given time period and weight them by the market prices of each of the goods or services',(Thoughtco,2019).

GDP $=$ Outputs of (Industry + Services + Agriculture). In this particular case of the report industry is subdivided in the Gold and non-Gold sectors. In effect $Y=F(K, L \ldots \ldots)$ 


\subsection{Hypotheses}

The field of mining has received a lot of researchers' attention (Mahonye and Mandisharay, 2015; Adjei, et al, 2015; Deller, 2014; Fernandes, 2014; Koitsiwe, 2018; Sudarlan, et al, 2015; Mensah, et al, 2015; Yeboah, 2008; Walser, undated; and Hlavova, 2015). In spite of the numerous studies, the focus and the findings have not been conclusive. A study of 48 economies in Sub-Saharan Africa for the years 1995 to 2013 by Hlavova (2015) did not reveal the relationship between the share of mineral resources in total export and economic growth in the category of mineral economies. Only a very weak effect has been demonstrated in other economies. Sudarlan, et al (2015) study in Indonesia asserted that the mining sector had had a negative impact on economic growth and economic growth was not significant statistically for poverty reduction. Mahonye and Mandisharay (2015) study in Zimbabwe for the period 1970 - 2008 accepted "the hypothesis of the presence of a resource curse in Zimbabwe. Actually, for the period under review the study couldnot reject the hypothesis that mineral resources have a negative impact on growth".

A critical analysis of both the theoretical and empirical literature reveals that mining plays a significant role in the economic performance of resource countries. Lawer, et al (2017) have argued that mining has provided jobs, improved revenue generation and fostered economic development in Ghana. Indeed, Ghana has been touted as a country that could avert the resource curse mantra (Green, 2008). Simply put, with the right usage of mining revenues, Ghana should experience rapid economic performance. Economic performance of a country has been measured by both macroeconomic and microeconomic indicators. The macroeconomic indicators have often been used to measure the economic performance of a country at the broad level. There are various indicators that are used to measure macroeconomic performance of a country. Some of these indicators are GDP, inflation, interest rate, exchange rate, stock market rate, and employment rate.

The study avers that if mining improves the economic fortunes and performance of a country, then it should translate into favourable or positive associations with 
macroeconomic indicators on the basis of the selected macroeconomic indicator, the following hypotheses were tested:

H1: There is a significant and positive correlation between gold mining production and real GDP

Hla: There is a significant and positive correlation between gold mining production and real GDPpc

The study states that increase in mining should lead to an increase in the gross domestic product of Ghana. Since mining output is a composite part of GDP calculation, an increase in mining should leads to exponential economic growth. In other words, if mining output is increasing and GDP is decreasing (a negative relationship), then it shows that other non-resource sector's performance may be declining, hence evidence of the Dutch disease.

This study also investigates the impact of gold extraction on the growth of other sectors of the economy by focusing on agricultural, services and industry growth. The question ofinterest is whether gold production has any spillover effects on the other sectors of the economy.

Services, industry, agriculture could be impacted by gold mining due a possible rise in local incomes, reduction in farming and negative externalities of farm soil fertility. Hilson,2002, mentioned that gold production, mainly small-scale production could result in a decrease in cultivation of economic crops like cocoa and cashew, which are a major source of foreign exchange for Ghana.Indeed, authors such as Koitsiwe (2018) indicated mining is positively associated with economic growth and development of Botswana. Empirical test results show that the mining sector is positively correlated with growth in both the service and manufacturing sectors of Botswana. Amponsah-Tawiah and Dartey- 
Baah (2011) study in Ghana also revealed that the minerals sector has made significant contributions to foreign exchange earnings and Gross Domestic Product (GDP) of Ghana.

\section{H2: There is a significant correlation between gold mining production and production} levels for each economic sector.

Sachs and Warner (2001), attempt to find the causes of resource curse and mining activities' spill over effects on other parts of the economy. They suggest that mining activities in resource endowed countries increase demand of non-traded goods which are key inputs for the manufacturing sector. Costs are thus increased for the sector while profits dwindle, while investments in the manufacturing sector reduces and production decreases. They confirm from natural observation that generally prices in countries are directly related to income levels. Resource endowed countries tend to lean towards higher levels of prices despite a comparatively fixed prices on the international level. Consequently, corporations in these countries have to compete with a higher than average price levels, this affects their ability to make profits negatively. They further investigate the effect on the ability to compete on the international front on growth rate of the manufacturing sector as well as export growth. Sachs and Warner (2001), concluded that there is a negative relationship between GDP growth and export growth for resource endowed countries. Moreover,one effect of resource curse is that resource abundance impedes manufacturing and there a tendency to create an uncompetitive manufacturing sector and subsequently resourceendowed nations did venture successfully in export driven industries.

H2a: Gold mining production has a positive correlation with industry 
Gylfason et al. (1999), and Gylfason (2000) in Sachs and Warner (2001), comment that it is empirically evident that resource rich countries pursuit of mining maywell crowdout entrepreneurship and or innovation, especially if remunerations in the mining sector increase sufficiently to entice budding potential inventors and entrepreneurs to seek employment in the mining sector.They noted, as a result,natural resource endowed countries areusually characterized by slower economic growth, lower business and business activity, lesser innovation and, poor economies.

However, a study by Walser (undated) in Chile, Bolivia, Peru, Mali and Papua New Guinea Mali asserted that mining has substantial social and economic benefits to the Mining communities. The most positive instances are related to the growth of local microenterprise activities. Koitsiwe (2018) study on the impact of mining on economic development in Botswana emphasised the fact that mineral revenues remain the major source for economic growth. The study further argued that the "mining sector has been positively associated with growth in the manufacturing and service sectors" in Botswana. Koitsiwe (2018) study thus confirms Walser (undated) by linking mining to the economic performance of non-resource industries. Tulip (2014) study in Australia reveals that the mining success is projected to have increased real per capita household disposable income by 13 percent over the decade to 2013 . "The boom contributed to a large appreciation of the Australian dollar that has weighed on other industries exposed to trade, such as manufacturing and agriculture" (Tulip, 2014).

H2b: Gold mining production has a positive correlation with services

Ocansey (2013) asserts most mines in Ghana, especially surface mines due to their nature, require large acreage of land. Most farmlands are thus acquired from farmers who are offered meager compensations in exchange for their lands. Top soil removal leads to 
land degradation and erosions which advertently affect biodiversity and the ecosystem. Pollutants from mine effluents pollute rivers and streams for irrigation.

An earlier study by Yeboah (2008) in Obuasi Municipality in Ghana although did not focus on economic growth also revealed negative impact of mining on the environment. Yeboah (2008) study showed that mining activities have given rise to land degradation (leading to decline in food production), pollution of water bodies and noise pollution in the area. Mensha, et al (2015) study in Prestea in Ghana on the impact of mining confirmed Yeboah (2008) study. Mensah, et al (2015) discovered "that mining activities (especially that resulting from illegal small-scale mining (popularly known as 'galamsey') deplete environmental resources such as water, soil, the landscape, vegetation, the ecosystem, among others".

H2c: Gold mining production has a positive correlation with agriculture 


\section{Methods}

This chapter highlights the procedure followed in conducting this study. The chapter has been classified according to the headings: research approach; research design; sources of data; data analysis; measurement variables and estimation technique.

\subsection{Research Approach}

The research approach is deductive and incorporates inductive approaches. In deductive research, what drives the study are the existing theory and hypotheses. The empirical data gathered are used to confirm or deny the theory which will help to revise the existing theory. On the other hand, the inductive approach begins by looking at the motivation of the research (a business problem, an organisation, an economic issue, etc.), and through investigation by several research methods, aims to generate results theory from the research (Greener, 2008). The final step with the inductive theory method is that the researcher may want to gather more data to test the circumstances in which the theory will hold or not (Bryman and Bell, 2011).

Abdullah and Nilsson (2013) argued that the two approaches are not mutually exclusive. In other words, the deductive approach may involve inductive approach when the empirical results of the study are reviewed against the chosen theory. The deductive approach seems to be in consonance with the study's methodology. This is evidenced by the fact that the study adopted extant theories such as the resource curse theory, Dutch disease and the theories of mining

\subsection{Research Strategy and Design}

The goal of the herein empirical analysis is to adopt a robust econometric technique to test the hypotheses outlined in section 2.6. To do so, the output approach for analyzing GDP was chosen since it gives explicit insights into the contribution of each economic sector, and the ability to isolate the potential impact of the goldmining sector. Once data collection and treatment were performed, the analysis proceeded by computing descriptive 
statistics and investigating potential issues related to multicollinearity, heteroskedasticity, and autocorrelation. Then, the appropriateness of adopting random versus fixed effects was assessed. Once all these statistical tests were performed, as shown below, we were able to identify an adequate estimation technique to test the hypotheses proposed in this study.

\subsection{Data Collection and Treatment}

This study uses longitudinal data for forty-six African countries, while paying particular attention to Ghana. The data covered the period of 1997 to 2016, that is, 20 years.Given that we adopted the output approach to analyze the performance of GDP in the selected countries, we followed by collecting data on GDP and the contributions of industry, agriculture, and services sectors, as well as for population levels from the World Development Indicators (WDI) published by the World Bank (2019).

It is noteworthy that the World Bank describes nominal GDP as "the sum of gross value added by all resident producers in the economy plus any product taxes and minus any subsidies not included in the value of the products. It is calculated without making deductions for depreciation of fabricated assets or for depletion and degradation of natural resources. Dollar figures for GDP are converted from domestic currencies using single year official exchange rates" (World Bank, 2019). Industry data from the World Bank (2019) "corresponds to ISIC divisions 10-45 and includes manufacturing (ISIC divisions 15-37). It comprises value added in mining, manufacturing, construction, electricity, water, and gas", whereas data for the Agricultural sector "corresponds to ISIC divisions 1-5 and includes forestry, hunting, and fishing, as well as cultivation of crops and livestock

production". Lastly, Services data “correspond to ISIC divisions 50-99. They include value added in wholesale and retail trade (including hotels and restaurants), transport, and government, financial, professional, and personal services such as education, health care, and real estate services".

Given our research focus on the impact of gold production, related data was gathered from the United States Geological Services (USGS, 2019). Gold prices for the period of interest were obtained from Statistica. 
All nominal data not gathered from the World Bank (2019) - i.e. gold prices - were transformed into constant 2010 US dollars using the annual GDP deflator computed from the World Bank (2019) data for GDP in current US dollars versus constant 2010 US dollars. Furthermore, due to data availability constrains - e.g. World Bank (2019) did not report GDP per capita on some years for a few countries - real GDP per capita was calculated by dividing the aggregate real GDP by the corresponding population level per year. Similarly, the per capita real output from each economic sector, namely, industry, services, agriculture and goldmining were also calculated from their real aggregates following the same methodology. Then, given that the World Bank (2019) includes mining output in the industry sector data, we subtracted the real value of gold production from the total industry real output so as to separate the impact of gold production from all other industrial output.

\subsection{Summary Statistics}

This study's empirical analysis begins by computing summary statistics for the variables of interest, both in per capita and aggregate levels in constant 2010 US dollars, during the time period of 1997 to 2016 . Below, tables 1 and 2 provide summary statistics for the African Economies in aggregate and per capita levels, respectively.

Table 1. Summary Statistics (Per capita) For Africa

\begin{tabular}{llllll}
\hline Variable & Obs & Mean & SD & Min & Max \\
\hline GDP & 920 & 1838.882 & 2105.882 & 186.6614 & 11925.78 \\
Gold & 920 & 15.69555 & 36.26172 & 0 & 253.8909 \\
Industry & 920 & 584.065 & 917.1753 & 6.698166 & 6338.241 \\
Services & 920 & 887.4367 & 1094.88 & 36.40827 & 6588.341 \\
Agriculture & 920 & 231.9263 & 127.1164 & 47.98578 & 852.8613 \\
\hline
\end{tabular}

In the table above are the averages of the predictor variables for the various countries of interest; all 920 observations for African countries with the exclusion of Djibouti, Equatorial Guinea, Eritrea, Libya, Somalia, South Sudan, Seychelles, Togo, 
which did not have data on gold values. Average values for GDP per capita, gold produced per capita, industry per capita, services per capita and agriculture sector values per capita were $1838.882,15.69555,584.065,887.437$ and 231.9263 constant US dollars respectively. Gold's contribution to GPD was the least as the average data shows for the last 20 years for the forty-six countries involved.

Table 2. Descriptive Statistics for Aggregate Variablesfor Africa

\begin{tabular}{llllll}
\hline Variable & Obs & Mean & SD & Min & Max \\
\hline GDP & 920 & $3.47 \mathrm{E}+10$ & $7.27 \mathrm{E}+10$ & $1.01 \mathrm{E}+08$ & $4.64 \mathrm{E}+11$ \\
Gold & 920 & $3.90 \mathrm{E}+08$ & $1.33 \mathrm{E}+09$ & 0 & $1.19 \mathrm{E}+10$ \\
Industry & 920 & $1.01 \mathrm{E}+10$ & $2.14 \mathrm{E}+10$ & $2.01 \mathrm{E}+07$ & $1.11 \mathrm{E}+11$ \\
Services & 920 & $1.70 \mathrm{E}+10$ & $3.98 \mathrm{E}+10$ & $6.66 \mathrm{E}+07$ & $2.73 \mathrm{E}+11$ \\
Agriculture & 920 & $5.30 \mathrm{E}+09$ & $1.15 \mathrm{E}+10$ & $1.13 \mathrm{E}+07$ & $9.58 \mathrm{E}+10$ \\
\hline
\end{tabular}

Table 2 above shows summary statistics for the aggregate levels of each variable when looking at the forty-six African economies as a whole. More interestingly, Table 3 below breaks down those statistics per country (as well as in per capita terms).

\section{*** INSERT HERE: TABLE 3 "Sample Descriptives" ***}

Given our particular interest in the case of Ghana, Table 4 and 5 below highlight the 20-year averages for the Ghanaian variables, both in per capita and aggregate levels, respectively.

Table 4. Summary Statistics (Per capita) For Ghana

\begin{tabular}{lrrrrr}
\hline Variable & \multicolumn{1}{l}{ Obs } & \multicolumn{1}{l}{ Mean } & \multicolumn{1}{l}{ SD } & \multicolumn{1}{l}{ Min } & \multicolumn{1}{l}{ Max } \\
\hline GDP & 20 & 1229.8 & 271.28 & 919.65 & 1659.5 \\
Gold & 20 & 118.74 & 29.612 & 73.531 & 192.86 \\
Industry & 20 & 196.59 & 124.4 & 79.808 & 472.89 \\
Services & 20 & 471.82 & 180.43 & 256.47 & 741.57 \\
Agriculture & 20 & 351.09 & 25.101 & 313.3 & 408.04 \\
\hline
\end{tabular}


Table 5. Descriptive Statistics for Aggregate Variablesfor Ghana

\begin{tabular}{lrllll}
\hline Variable & Obs & \multicolumn{1}{l}{ Mean } & SD & Min & Max \\
\hline GDP & 20 & $2.86 \mathrm{E}+10$ & $1.05 \mathrm{E}+10$ & $1.62 \mathrm{E}+10$ & $4.68 \mathrm{E}+10$ \\
Gold & 20 & $2.70 \mathrm{E}+09$ & $8.58 \mathrm{E}+08$ & $1.29 \mathrm{E}+09$ & $4.96 \mathrm{E}+09$ \\
Industry & 20 & $4.72 \mathrm{E}+09$ & $3.69 \mathrm{E}+09$ & $1.96 \mathrm{E}+09$ & $1.25 \mathrm{E}+10$ \\
Services & 20 & $1.12 \mathrm{E}+10$ & $5.60 \mathrm{E}+09$ & $4.52 \mathrm{E}+09$ & $2.02 \mathrm{E}+10$ \\
Agriculture & 20 & $7.92 \mathrm{E}+09$ & $1.22 \mathrm{E}+09$ & $5.79 \mathrm{E}+09$ & $9.82 \mathrm{E}+09$ \\
\hline
\end{tabular}

It can be observed from the above summary statistics that Ghana's average GDP per capita (constant 2010 US dollars) from the years under study is about 1230 dollars, this is below the average GDP per capita for the rest of the Africa which stands at about 1839 dollars. Ghana GDP per capita compared to South Africa's, the leading gold producer in Africa and the second in the world, which stands at an average of 6744 dollars, is relatively low and begs the question whether the country has benefited in any meaningful way from mining Gold. This data is not conclusive enough as other factors like revenue from tourism may have boosted South Africa's economy. Comparing Ghana's GDP per capita to its west African gold producer counterpart - Ivory Coast -with GDP per capita of 1295 dollars, Ghana can be said to have performed slightly worse.

\subsection{Estimation Technique}

First, we took the natural log of all variables, either in aggregate or per capita levels, given that we are primarily focusing on testing the potential impact of gold production on economic growth. Then, to determine the proper estimation technique given the characteristics of our longitudinal dataset, statistical tests for multicollinearity, heteroscedasticity and autocorrelation were performed. Variance inflation factor yielded an average value of 1.84 , while none of the individual factors were greater than 3 , hence indicating that there were no issues with multicollinearity. The Breusch-Pagan test for 
heteroscedasticity and the White test for homoscedasticity were executed. Homoscedasticity was rejected by both tests so there exist heteroscedasticity, and consequently robust errors will be employed. The Woolridge test for autocorrelation was also performed on the data and autocorrelation was established, confirming the need to use robust errors in the analysis.

Then, the Hausman test was performed and it recommended the usage of fixed effects models. This suggestion was confirmed by the Breusch-Pagan Lagrangian multiplier. Therefore, the proper estimation technique to test the hypotheses stated in section 2.6 was determined to be Ordinary Least Squares models (xtreg command in Stata 14) with fixed effects and robust standard errors to analyze the African economies as a whole.

For the case of Ghana - single country analysis - the same tests and methodology outlined above were employed. The results suggested that the proper hypotheses testing for Ghana should employ an Ordinary Least Squares model (reg command in Stata 14) with random effects. For the sake of consistency alone, we decided to adopt robust standard errors as well.

Therefore, and generally speaking, the estimated model assumes the following general form: $Y_{i t}=\beta_{0} C+\beta X_{i t}+e$, where $Y$ stands for the dependent variable (either GDP or GDP per capita), $C$ refers to the constant/intercept, $X$ stands for the matrix of dependent variables (either in aggregate or per capita form), comprising output from gold, industry, services, and agricultural sectors, $i$ stands for the individual country, $t$ captures the year of the observation, and $e$ refers to the error term. More, the estimation technique assumes a linear relationship between the dependant variable and the independent variables.

To infer about the robustness of the econometric results, 6 models were adopted. The first model is merely a preliminary and simple model that evaluates the potential impact of gold production alone on GDP, either at the aggregate or per capita level. The second model is the foundational theoretical model, that is, the decomposition of GDP according to the output approach, where gold has been separated from industrial output. 
The third model expands the foundational model based on extant empirical literature by incorporating one lag of GDP (either aggregate or per capita). The fourth model extends the previous model by incorporating potential time effects. Then, the fifth model adds interactions effects to investigate potential spillover effects that gold production may have on other economic sectors. Finally, the sixth model expands on the fifth model by incorporating any potential impact from time effects. 


\section{Econometric Results and Discussion}

The econometric results are first presented for the models analysing the African economies as a whole (Tables $6 \mathrm{a}$ and $6 \mathrm{~b}$ ), and then proceed to the results for the case of Ghana alone (Tables $7 \mathrm{a}$ and $7 \mathrm{~b})$.

$* * *$ INSERT HERE ***

Table 6a. Regression output of GDP on independent variables For Africa

Table 6b. Regression output of GDPpc on independent variables For Africa

Table 7a. Regression output of GDP on independent variables For Africa

Table 7b. Regression output of GDPpc on independent variables For Africa

Testing hypotheses and related robustness involved the evaluation of six econometric models, as described below, using a dataset covering the period of 1997 to 2016 (i.e. 20 years). In our discussion, we will first focus on the statistical results for the overall fortysix African economies and then assess if those relationships hold when we look at the case of Ghana alone. The statistically analysis focuses on finding statistical support to reject or fail to reject this study's hypotheses, and it refrains from commenting on the size of the coefficients associate with gold output. The latter results from the fact that gold output represents a sub-sector of the industrial sector so comparisons against entire economic sectors would likely not be very meaningful.

\subsection{First Model}

The first model offers an over simplistic assessment of the potential impact that growth in gold mining output may have on the growth rate of GDP, both in terms of overall GDP and GDP per capita. As shown in Tables 6a and 6b, there is a positive and statistically significant relationship at the $99.9 \%$ confidence level between the growth rates of gold output and GDP or GDP per capita. When applying this first model to Ghana alone, we found that the same relationship and statistical significance holds when overall growth in GDP is assessed (Table 7a) but when focusing on GDP per capita growth (Table 7b) there is no statistical significance. Despite these preliminary insights, everything else being 
captured by the constant/intercept warrants further investigation to validate said relationships as corroborated by the low R-square in each regression.

\subsection{Second Model}

Model 2 is construed directly from macroeconomic theory, namely the output approach of GDP, and serves as the first model to test hypotheses H1 and H1a. In this context, the growth rates of each economic sector, namely gold, industry, services, and agriculture were regressed against GDP. This exercise was made both when all variables were expressed in aggregate (Tables $6 \mathrm{~b}$ and $7 \mathrm{~b}$ ) and per capita (Tables 6a and 7a) growth rates.

The statistical results show strong support of macroeconomic theory and the role of gold output on economic performance and therefore we fail to reject our hypotheses $\mathrm{H} 1$ and H1a. In particular, Model 2 in Tables 6a and 7a support H1 both for the African economies as a whole as well as Ghana alone at the $99 \%$ confidence level, that is, there is strong evidence of a significant and positive correlation between gold mining production and real GDP. Concurrently, when evaluating said relationship in per capita terms (Tables $6 \mathrm{~b}$ and $7 \mathrm{~b}$ ), we also fail to reject $\mathrm{H} 1 \mathrm{a}$ at the $99.9 \%$ confidence level when looking at African economies as a whole, and at the $99 \%$ confidence level when looking at Ghana alone.

Model 2 also does a good job capturing economic activity for African economies or Ghana as evidenced by the relatively high R-square values. Model 2 for all African economies (Table 6a) achieved an R-square of 0.970 whereas this same model for Ghana recorded an R-square of 0.996 (Table 7a). For the per capita models, we observe similar values for R-square, namely 0.972 in Table $6 \mathrm{~b}$ and 0.990 in Table $7 \mathrm{~b}$.

It is also noteworthy that all the remaining economic sectors show highly significant relationships with GDP or GDP per capita at the $99.9 \%$ confidence level in all simulations of Model 2, which further lends support to validity of this model and macroeconomic theory in general. 


\subsection{Third Model}

To further investigate the robustness of the econometric results shown in Model 2, the lag of GDP per capita was added to the model so as incorporate the teachings of extant literature on economic growth and development, in particular the empirical evidence that GDP growth rates tend to have a strong relationship with prior GDP performance - both in aggregate and per capital levels. Thus Model 3 serves as the benchmark model to test hypotheses $\mathrm{H} 1$ and H1a.

As shown in Model 3 in Tables 6a and 7a, even with the inclusion of lagged GDP, we still fail to reject $\mathrm{H} 1$ at the $99.9 \%$ and $95 \%$ confidence level, respectively, thus the statistical analyses continue to support that there is a significant and positive relationship between gold output and real GDP, both for Ghana and the African economies as a whole. In terms of economic performance in per capita terms, Tables $6 \mathrm{~b}$ and $7 \mathrm{~b}$, show similar support for failing to reject H1a, namely at the $99 \%$ and $95 \%$ confidence level. It is noteworthy that the addition of lagged GDP to model 2 - that is, Model 3 - lead to an increase in R-square to levels greater than 0.99 in all cases, thus supporting the suggestion of extant empirical literature on economic growth and development about the relevance of including lagged GDP when statistically investigating growth experiences.

\subsection{Fourth Model}

Given that Africa is known for its political instability we decided to further test the robustness of the statistical results by adding time effects (year effects) - Model 4. However, this model was only feasible for the scenario of African economies as whole due to collinearity issues arising from the inclusion of time effects when studying Ghana alone. Nonetheless, Model 4 in Tables $6 \mathrm{a}$ and $6 \mathrm{~b}$ show that the inclusion of time effects did not retract statistical support for the prevalence of a significant and positive relationship between gold output and real GDP, both in aggregate (H1) and per capita terms (H1a), and therefore lending additional support to the validity of our results. 


\subsection{Fifth Model}

Within the realm of testing hypotheses $\mathrm{H} 2$ and thus $\mathrm{H} 2 \mathrm{a}, \mathrm{H} 2 \mathrm{~b}$, and $\mathrm{H} 2 \mathrm{c}$, model 5 expands model 3 by including potential interaction effects between gold output and output from the remaining economic sectors. We tested these hypotheses both at the aggregate and per capita levels.

In terms of aggregate growth rates, the results for Model 5 in Tables 6a and 7a show that we reject $\mathrm{H} 2 \mathrm{a}$ at the $99 \%$ confidence level both for African economies as a whole and Ghana alone. That is, there is strong statistical evidence that gold output has a negative interaction effect with industrial output, suggesting that increasing levels of gold output tend buffer growth in industrial output. This finding lends support to the "Dutch disease" discussed earlier on. However, when investigating the relationship between gold and services output we fail to reject $\mathrm{H} 2 \mathrm{~b}$ at at the $99 \%$ confidence level, both for African economies as a whole and Ghana alone. That is, there is strong statistical evidence that gold output has a positive interaction effect with services output, suggesting that increasing levels of gold output tend augment growth in services output.Unfortunately, the current study is unable to assess if this potential positive impact of gold output on services output outweighs the negative impact that gold output seems to have on industrial output. Future research is needed to evaluate the overall net effect on societal welfare.

When it comes to the analysis in per capita terms, Tables $6 \mathrm{~b}$ and $7 \mathrm{~b}$, show similar results for $\mathrm{H} 2 \mathrm{a}$ at the $95 \%$ confidence level, that is, higher gold output per capita tends to buffer industrial output per capita. In relation to the potential positive impact of gold output on services output, we only find statistical support for $\mathrm{H} 2 \mathrm{~b}$ at the $95 \%$ confidence level when analyzing the forty-six African economies as a whole. When testing $\mathrm{H} 2 \mathrm{~b}$ in per capita terms for Ghana alone, said interaction effect is not statistically significant.

Lastly, we were unable to find statistical evidence for the potential role that gold output may have on agricultural output. In none of our models said interaction effect was statistically significant thus suggesting that gold output may not have a statistically meaningful impact on the agricultural sector. 


\subsection{Sixth Model for Africa}

Model 6 was built with the intention of serving as a robustness check to Model 5, by extending it to include time effects given the know political instability in African countries. Unfortunately, and similar to the case of Model 4, Model 6 was only feasible when assessing the forty-six African economies as a whole due to collinearity issues when evaluating the case of Ghana alone. However, as shown in Tables 6a and 6b, adding time effects did not change the statistical inferences for $\mathrm{H} 2 \mathrm{a}$ and $\mathrm{H} 2 \mathrm{~b}$ under Model 5 when jointly examining all African economies in our study, albeit the decrease in significance level for $\mathrm{H} 2 \mathrm{a}$ from $99 \%$ to $95 \%$ confidence level - all other confidence levels remained unchanged. These results lend additional support to our conclusions about $\mathrm{H} 2 \mathrm{a}$ and $\mathrm{H} 2 \mathrm{~b}$ when assessing them for the African economies as a whole. 


\section{Conclusion and Future Research}

The aim of this study was tocompare the impact of goldmining on the economic performance of African economies while paying particular attention to the country of Ghana, and taking into account the role of other economic sectors, namely, services, industry and agriculture. The study sought to achieve this aim by performing two major activities. The first activity was the review of both theoretical and empirical literatures related to the study and the subsequent development of hypotheses to test with secondary data.

The second activity was the analysis of secondary data to confirm or deny the study's five hypotheses. The statistical analysis of secondary data revealed that for both Ghana and Africa, as gold production increases, GPD growth increases, both at the aggregate and per capita levels, however a more granular analysis based on interaction effects between gold production and other economic sectors indicated that gold mining may have buffered industrial production while concurrently augmenting output in the services sector. These potential trade-offs have important implications for policy making in African economies and their pursuit of an optimal allocation of resources that fosters sustainable economic growth and development. In particular, the finding of a potential negative moderation effect between gold mining and industrial output suggests the prevalence of the "Dutch Disease" though this negative effect may be offset by the positive effect that gold mining seems to have on services output.

In sum, based on the most recent data available for African nations, this study has contributed to extant literature by performing a thorough investigation on how gold production may promote economic growth, albeit potential trade-offs across economic sectors. The statistical results have important implications for policy makers in Africa, as they struggle to find optimal policies to promote sustainable economic growth and development.

This study assessed the impact of gold production on GDP and other economic sectors. However, it did not assess if the positive effect that gold mining has on services output outweighs the negative impact that it seems to have on industrial output. Future 
research should explore if the summation of these effects leads to gains or losses in national welfare. On the other hand, this study also did not investigate the relationship between gold production and the prevalence of poverty in Africa. Future studies could examine the role that gold production may have in poverty eradication in Ghana and other gold producing countries. 


\section{Reference List}

Abdullah, Y., and Nilsson, F. (2013). Impact of Exchange Rates on Swedish Stock Performances: Empirical study on USD and EUR exchange rates on the Swedish stock market. Unpublished degree project, Umea School of Business and Economics, spring 2013: 1-101.

Acheampong, E. (2004). Impact Assessment of Mining Activities by Ashanti GoldfieldsBibiani Limited on the Environment and Socio-Economic Development of Bibiani. Unpublished Undergraduate Dissertation, Faculty of Social Sciences, Kwame Nkrumah University of Science and Technology: 1-22

Adjei, S., Oladejo, N.K., and Adetunde, I.A. (2012). The Impact and Effect of Illegal Mining (galamsey) towards the Socio-economic Development of Mining Communities: A Case Study of Kenyasi in the Brong Ahafo Region. International Journal of Modern Social Sciences, 1(1): 38-55

Akabzaa T. (2007). African mining codes, a race to the bottom. African Agenda,.7(3): 62- 63.

Akabzaa, T., and Dariamani, A., (2001). A study of impacts of mining sector investment in Ghana on mining communities. Report prepared for the Technical Committee on Structural Adjustment Participatory Review Initiative (SAPRI) on Ghana: 65.

Amponsah-Tawiah, K. and Dartey-Baah, K. (2011). The Mining Industry in Ghana: A Blessing or a Curse. International Journal of Business and Social Science, 2(12): 62-69

(Anonymous, undated). Introduction to Mining: 1-24

Badeeb, R.A., Leana, H.H., and Clark, R. (2017). The evolution of the natural resource curse thesis: A critical literature Survey. Resources Policy, 51: 123-134

Bank of Ghana (2003). Report on the Mining Sector. Research Department Sector Study, 1(2): $1-69$

Baumohl, B. (2008). The secrets of economic indicators, 2nd edition. Wharton School publishing

Bloch R. and Owusu. G (2012). Linkages in Ghana's gold mining industry: Challenging the enclave thesis.

Bryman, A. and Bell, E., (2011). Business Research Methods. 3rd edition, Oxford University Press.

Davis, G.A. and Tilton, J. E. (2002). Should Developing Countries Renounce Mining? A Perspective on the Debate. Version Dec 12: 1-61 
Deller, S. (2014). Does Mining Influence Rural Economic Growth? The Journal of Regional Analysis and Policy, 44(1): 36-48

Glenn-Marie, L. (2003). The contribution of minerals to sustainable economic development: Mineral resource accounts in Namibia. Dea Research Discussion Paper, 54: $1-34$

Green, M., (2008). Crude Realities. Financial Times, 27 August 2008. InLawera, E.T., Lukasb, M.C, and Jørgensenc, S.H. (2017). The neglected role of local institutions in the 'resource curse' debate. Limestone mining in the Krobo region of Ghana. Resources Policy, 54 (2017): 43-52

Greener, S. (2008). "Business Research Methods". Dr Sues Greener \&Ventus Publishing: 1-110, ISBN 978-87-7681-421-2.

Hilson G. (2019). Why is there a large-scale mining 'bias' in sub-Saharan Africa? Land Use Policy, Volume 81, February 2019, Pages 852-861

Hilson, G., Gillani, A., and Kutaula, S., (2015) Towards Sustainable Pro-Poor Development? A Critical Assessment of Fair-Trade Gold. Journal of Cleaner Production, Volume 186, 10 June 2018, Pages 894-904

Hilson, G., \&Hilson, A. (2017). Mining in Ghana: Critical Reflections on the Turbulent Past and Uncertain Future. In E. Aryeetey, \& R. Kanbur (Eds.), The Economy of Ghana Sixty Years After Independence (pp. 260-276). [16] OXFORD: Oxford University Press.

Hlavová, N. (2015). The impact of mineral resources on economic growth. International Journal of Arts and Commerce, 4 (6): 100-110

Keele L. and. Kelly N. J (2005). Dynamic Models for Dynamic Theories: The Ins and Outs of Lagged Dependent Variables

Koitsiwe, K. (2018). The Impact of Mining Sector on Economic development in Botswana. Unpublished Doctoral Thesis, Akita University: 1-106

Kovářová, E. (2015). Foreign Direct Investment Inflows to Africa: Overview and Current Trends. Journal of International Relations, 1, 69-86.

Khramov, V. and Lee, J. R. (2012). The Economic Performance Index (EPI): An Intuitive Indicator for Assessing a Country's Economic Performance Dynamics in an Historical Perspective. International Monetary Fund, working Paper, WP/13/214: 1-60

Kronenberg Tobias (2004). The curse of natural resources in the transition economies, https://doi.org/10.1111/j.0967-0750.2004.00187.x 
Lawera, E.T., Lukasb, M.C, and Jørgensenc, S.H. (2017). The neglected role of local institutions in the 'resource curse' debate. Limestone mining in the Krobo region of Ghana”. Resources Policy, 54 (2017): 43-52

Mahonye, N and Mandishara, L. (2015). Mechanism Between Mining Sector and Economic Growth in Zimbabwe, Is it a Resource Curse?. Economic Research Southern Africa (ERSA), ERSA working paper 499: 1-23

Mensah, A.K., Mahiri, I.O., Owusu, O., Mireku, O.D., Wireko, I. and Kissi, E.A. (2015). Environmental Impacts of Mining: A Study of Mining Communities in Ghana. Applied Ecology and Environmental Sciences, 3(3): 81-94

Ocansey, I.T. (2013), Mining Impacts on Agricultural Lands and Food Security: Case study of towns in and around Kyebi in the Eastern Region of Ghana. Bachelor's thesis in International Business. Turku University of Applied Sciences Thesis

Olsen, A. R. (2009). Business cycle forecasting through economic indicators: A dynamic approach. Unpublished MSc in Economics and Business Administration Thesis, University of Copenhagen: 1-25

Perman, R., Ma, Y., McGilvray, J., and Common, M. (2003). Natural Resource and Environmental Economics. Harlow: Pearson Education Limited.

Sachs J. D., and Warner, A. M., (2001), The curse of natural resources, European Economic Review, Volume 45, Issues 4-6, May 2001, Pages 827-838

Saunders, M., Lewis, P. and Thornhill, A. (2007). Research Methods for Business Statistics. 4th Edition, Essex, England, Pearson Education Ltd: 117-515.

Saunders, M., Lewis, P. and Thornhill, A., (2012). Research Methods for Business Students. 6th Edition, Essex, England, Pearson Education Ltd: 1- 400.

Soubbotina, T. P. (2004). Beyond Economic Growth: An Introduction to Sustainable Development. (2nded.) Washington, D.C.: The World Bank.

Stiglitz, J. E. (2017). The Measurement of Economic Performance and Social Progress. International Economic Association World Congress, Mexico City: 1-32

Stiglitz, J. E., Sen, A., and Fitoussi, J-P (2008). Report by the Commission on the Measurement of Economic Performance and Social Progress. Government of France: 135

Sudarlan, Indiastuti, R., and Yusuf, A.A. (2015). Impact of Mining Sector to Poverty and Income Inequality in Indonesia: A Panel Data Analysis. International Journal of Scientific and Technology Research, 4(6): 195-200 
Tulip, T. (2014). The Effect of the Mining Boom on the Australian Economy. December quarter, Bulletin: 19-22

Walser, G. (Undated). Economic impact of world mining. Bank Group Mining Department, Washington, D.C., United States of America: 86-88

Wikipedia Free Encyclopedia, (2019). Mining. Available at http://en.wikipedia.org/wiki/Mining. Accessed on 14/02/2019

Wikipedia Free Encyclopedia, (2019). Mining Industry of Ghana. Available at https://en.wikipedia.org/wiki/Mining_industry_of_Ghana. Accessed 14/02/2019

Yeboah, J. Y. (2008). Environmental and Health impact of Mining on Surrounding Communities: A Case study of Anglogold Ashanti in Obuasi, Unpublished Master of Arts thesis, Kwame Nkrumah University of Science and Technology, Ghana: 1- 85

Thought.co (2019), Calculating gross domestic product, available at www.thought.com(https://www.thoughtco.com/calculate-gross-domestic-productusingvalueadded-1147520)- accessed 05/15/2019

The World Bank (2019), World Development Indicators, Available at (http://databank.worldbank) accessed 2/23/2019

United States Geological Services, National Minerals Information Center, Gold Statistics and Information (2019), available at (https://minerals.usgs.gov/minerals/pubs/commodity/gold/)- accessed 3/14/2019

Statisticawebsite (2019), Price of gold per troy ounce from 1990 to 2018 (in U.S. dollars), available at (https://www.statista.com/statistics/274001/gold-price-per-ounce-since1978/)-2/23/2019) Accessed -2/23/2019)

IMF Working, Paper. (2017), Are Local Communities Better Off? A co-publication of the AgenceFrançaise de Développement and the World Bank pg. 147 


\section{Appendix}

\subsection{Table 3. Sample Descriptives}

\begin{tabular}{|c|c|c|c|c|c|c|c|c|c|c|}
\hline \multirow[b]{2}{*}{ Country } & \multicolumn{2}{|c|}{ GDP } & \multicolumn{2}{|c|}{ GOLD } & \multirow{2}{*}{\multicolumn{2}{|c|}{$\begin{array}{c}\text { INDUSTRY } \\
\text { Per Capita Total }\end{array}$}} & \multicolumn{2}{|c|}{ SERVICES } & \multirow{2}{*}{\multicolumn{2}{|c|}{$\begin{array}{c}\text { AGRIC } \\
\text { Per Capita Total }\end{array}$}} \\
\hline & Per Capita & Total & Per Capita & Total & & & Per Capita & Total & & \\
\hline Algeria & 4159.04 & $1.5 \mathrm{E}+11$ & 0.32 & $1 \mathrm{E}+07$ & 2018.12 & $7 \mathrm{E}+10$ & 1560.62 & $5.5 \mathrm{E}+10$ & 391.48 & $1.37 \mathrm{E}+10$ \\
\hline Angola & 3037.92 & $6.7 \mathrm{E}+10$ & 0.00 & 0 & 1673.62 & $3.6 \mathrm{E}+10$ & 1174.00 & $2.65 \mathrm{E}+10$ & 207.63 & $4.58 \mathrm{E}+09$ \\
\hline Benin & 744.99 & $6.3 \mathrm{E}+09$ & 0.17 & $1 \mathrm{E}+06$ & 173.18 & $1.5 \mathrm{E}+09$ & 319.44 & $2.75 \mathrm{E}+09$ & 181.64 & $1.52 E+09$ \\
\hline Botswana & 5972.70 & $1.2 \mathrm{E}+10$ & 20.50 & $4 \mathrm{E}+07$ & 2211.65 & $4.3 E+09$ & 3050.16 & $6 \mathrm{E}+09$ & 147.81 & $2.86 \mathrm{E}+08$ \\
\hline Burkina Fasso & 532.15 & $7.8 \mathrm{E}+09$ & 32.88 & $6 \mathrm{E}+08$ & 68.15 & $9.3 E+08$ & 224.75 & $3.32 \mathrm{E}+09$ & 173.98 & $2.53 \mathrm{E}+09$ \\
\hline Burundi & 229.88 & $1.8 \mathrm{E}+09$ & 2.24 & $2 \mathrm{E}+07$ & 32.92 & $2.6 \mathrm{E}+08$ & 85.62 & $6.95 \mathrm{E}+08$ & 90.49 & $7.09 \mathrm{E}+08$ \\
\hline C.Africa Rep. & 405.59 & $1.7 \mathrm{E}+09$ & 0.30 & $1 \mathrm{E}+06$ & 55.08 & $2.3 E+08$ & 125.49 & $5.23 \mathrm{E}+08$ & 201.91 & $8.35 \mathrm{E}+08$ \\
\hline Cameroon & 1282.76 & $2.4 \mathrm{E}+10$ & 2.25 & $4 \mathrm{E}+07$ & 348.27 & $6.5 \mathrm{E}+09$ & 644.53 & $1.21 \mathrm{E}+10$ & 192.48 & $3.54 \mathrm{E}+09$ \\
\hline Capae Verde & 2792.62 & $1.4 \mathrm{E}+09$ & 0.00 & 0 & 531.48 & $2.6 \mathrm{E}+08$ & 1789.23 & $8.7 \mathrm{E}+08$ & 255.95 & $1.23 \mathrm{E}+08$ \\
\hline Chad & 738.49 & $8.3 \mathrm{E}+09$ & 0.13 & $1 \mathrm{E}+06$ & 106.61 & $1.2 \mathrm{E}+09$ & 260.56 & $2.86 E+09$ & 346.69 & $3.95 \mathrm{E}+09$ \\
\hline Comoros & 1297.41 & $8.3 \mathrm{E}+08$ & 0.00 & 0 & 155.40 & $1 \mathrm{E}+08$ & 704.00 & $4.52 \mathrm{E}+08$ & 385.18 & $2.48 \mathrm{E}+08$ \\
\hline Congo & 2564.64 & $1 \mathrm{E}+10$ & 0.91 & $4 \mathrm{E}+06$ & 1718.32 & $6.9 \mathrm{E}+09$ & 701.48 & $2.8 \mathrm{E}+09$ & 143.92 & $5.63 \mathrm{E}+08$ \\
\hline Congo Dem. Rep & 331.72 & $2 \mathrm{E}+10$ & 5.83 & $4 \mathrm{E}+08$ & 103.88 & $6.4 \mathrm{E}+09$ & 119.77 & $7.13 E+09$ & 87.92 & $4.97 \mathrm{E}+09$ \\
\hline Egypt & 2270.79 & $1.8 \mathrm{E}+11$ & 1.39 & $1 \mathrm{E}+08$ & 785.40 & $6.4 \mathrm{E}+10$ & 1094.93 & $8.89 \mathrm{E}+10$ & 306.14 & $2.44 \mathrm{E}+10$ \\
\hline Ethiopia & 296.38 & $2.5 \mathrm{E}+10$ & 2.38 & $2 \mathrm{E}+08$ & 34.98 & $3 E+09$ & 114.53 & $9.76 \mathrm{E}+09$ & 122.87 & $1.03 \mathrm{E}+10$ \\
\hline Gabon & 9698.03 & $1.4 \mathrm{E}+10$ & 9.00 & $2 \mathrm{E}+07$ & 5115.33 & $7.7 \mathrm{E}+09$ & 3514.14 & $5.19 \mathrm{E}+09$ & 503.81 & $7.25 \mathrm{E}+08$ \\
\hline Gambia & 526.91 & $8.1 \mathrm{E}+08$ & 0.00 & 0 & 74.34 & $1.1 \mathrm{E}+08$ & 304.45 & $4.67 \mathrm{E}+08$ & 125.86 & $1.94 \mathrm{E}+08$ \\
\hline Ghana & 1229.80 & $2.9 \mathrm{E}+10$ & 118.74 & $3 E+09$ & 196.59 & $4.7 \mathrm{E}+09$ & 471.82 & $1.12 \mathrm{E}+10$ & 351.09 & $7.92 \mathrm{E}+09$ \\
\hline Guinea & 628.35 & $6.4 \mathrm{E}+09$ & & $5 \mathrm{E}+08$ & 145.94 & $1.5 \mathrm{E}+09$ & 269.04 & $2.76 \mathrm{E}+09$ & 118.66 & $1.2 \mathrm{E}+09$ \\
\hline Guinnea & 5.69 & $7.9 \mathrm{E}+08$ & 0.00 & 0 & 76.02 & $1.1 \mathrm{E}+08$ & 206.45 & $3.03 E+08$ & 249.38 & $3.62 \mathrm{E}+08$ \\
\hline Ivory Coast & 1295.48 & $2.5 \mathrm{E}+10$ & 11.79 & $3 E+08$ & 292.76 & $5.7 \mathrm{E}+09$ & 653.12 & $1.24 \mathrm{E}+10$ & 305.85 & $5.85 \mathrm{E}+09$ \\
\hline Kenya & 930.73 & $3.6 \mathrm{E}+10$ & & $4 \mathrm{E}+07$ & 159.48 & $6.2 \mathrm{E}+09$ & & $1.74 \mathrm{E}+10$ & 243.75 & $9.44 \mathrm{E}+09$ \\
\hline Lesotho & 1058.80 & $2.1 \mathrm{E}+09$ & 0.00 & 0 & 354.91 & $7.1 \mathrm{E}+08$ & 564.27 & $1.13 \mathrm{E}+09$ & 64.24 & $1.28 \mathrm{E}+08$ \\
\hline Liberia & 561.54 & $1.9 \mathrm{E}+09$ & 3.60 & $1 \mathrm{E}+07$ & 37.83 & $1.4 \mathrm{E}+08$ & 178.33 & $6.69 \mathrm{E}+08$ & 342.42 & $1.12 \mathrm{E}+09$ \\
\hline Madagas & & $8 \mathrm{E}+09$ & 0.04 & & 70.72 & $1.4 \mathrm{E}+09$ & & $3.91 \mathrm{E}+09$ & 106.83 & $2.04 \mathrm{E}+09$ \\
\hline Malawi & 416.18 & $5.9 \mathrm{E}+09$ & 0.00 & 0 & 65.65 & $9.2 \mathrm{E}+08$ & 187.55 & $2.69 \mathrm{E}+09$ & 129.09 & $1.8 \mathrm{E}+09$ \\
\hline Mali & 655.02 & $9.1 \mathrm{E}+09$ & 87.22 & $1 \mathrm{E}+09$ & 51.05 & $6.7 \mathrm{E}+08$ & 237.61 & $3.3 \mathrm{E}+09$ & 222.57 & $3.11 \mathrm{E}+09$ \\
\hline Mauri & & $3.9 \mathrm{E}+09$ & & $2 \mathrm{E}+08$ & & $1.1 \mathrm{E}+09$ & & $1.37 \mathrm{E}+09$ & 294.90 & $9.65 \mathrm{E}+08$ \\
\hline Mauritius & 7079.64 & $8.7 \mathrm{E}+09$ & 0.00 & 0 & 1633.89 & $2 E+09$ & 4298.29 & $5.31 E+09$ & 324.05 & $3.96 \mathrm{E}+08$ \\
\hline Morocco & 2538.16 & $8.1 \mathrm{E}+10$ & 0.69 & $2 \mathrm{E}+07$ & 667.73 & $2.1 \mathrm{E}+10$ & 1311.38 & $4.15 \mathrm{E}+10$ & 331.01 & $1.05 \mathrm{E}+10$ \\
\hline Mozambiqu & & $8.5 \mathrm{E}+09$ & & $4 \mathrm{E}+06$ & & $1.6 \mathrm{E}+09$ & & $4.23 E+09$ & 90.53 & $2.09 \mathrm{E}+09$ \\
\hline Namibia & 4754.87 & $1 \mathrm{E}+10$ & 45.54 & $1 \mathrm{E}+08$ & 1281.05 & $2.7 \mathrm{E}+09$ & 2706.58 & $5.76 \mathrm{E}+09$ & 398.53 & $8.36 \mathrm{E}+08$ \\
\hline Niger & 347.14 & $5.2 \mathrm{E}+09$ & 3.07 & $5 E+07$ & 55.32 & $8.3 \mathrm{E}+08$ & 143.59 & $2.11 \mathrm{E}+09$ & 131.34 & $1.96 \mathrm{E}+09$ \\
\hline Nigeria & & $3 \mathrm{E}+11$ & 0.50 & $9 \mathrm{E}+07$ & 502.63 & $7.5 \mathrm{E}+10$ & 951.89 & $1.46 \mathrm{E}+11$ & 481.29 & $7.16 \mathrm{E}+10$ \\
\hline Rwanda & 489.21 & $4.8 \mathrm{E}+09$ & 0.16 & $2 \mathrm{E}+06$ & 76.75 & $7.6 \mathrm{E}+08$ & 225.91 & $2.24 \mathrm{E}+09$ & 159.03 & $1.53 E+09$ \\
\hline Sao Tome \&Principe & 1016.84 & $1.7 \mathrm{E}+08$ & 0.00 & 0 & 168.67 & $2.8 \mathrm{E}+07$ & 729.75 & $1.21 \mathrm{E}+08$ & 111.68 & 18609828 \\
\hline Senegal & 1203.75 & $1.5 \mathrm{E}+10$ & 8.08 & $1 \mathrm{E}+08$ & 256.99 & $3.1 \mathrm{E}+09$ & 628.82 & $7.61 \mathrm{E}+09$ & 177.32 & $2.12 \mathrm{E}+09$ \\
\hline Sierra Leone & 382.24 & $2.3 \mathrm{E}+09$ & 0.48 & $3 E+06$ & 48.74 & $2.8 \mathrm{E}+08$ & 118.86 & $7.28 \mathrm{E}+08$ & 201.14 & $1.21 \mathrm{E}+09$ \\
\hline South Africa & 6744.23 & $3.4 \mathrm{E}+11$ & 171.40 & $8 \mathrm{E}+09$ & 1688.28 & $8.4 \mathrm{E}+10$ & 4052.19 & $2.03 \mathrm{E}+11$ & 179.21 & $8.87 \mathrm{E}+09$ \\
\hline Sudan & 1369.13 & $5.2 \mathrm{E}+10$ & 25.62 & $9 \mathrm{E}+08$ & 397.21 & $1.3 \mathrm{E}+10$ & 652.14 & $2.16 \mathrm{E}+10$ & 492.67 & $1.58 \mathrm{E}+10$ \\
\hline Swaziland & 3455.40 & $4 \mathrm{E}+09$ & 0.00 & 0 & 1313.66 & $1.5 \mathrm{E}+09$ & 1603.39 & $1.88 \mathrm{E}+09$ & 364.51 & $4.22 \mathrm{E}+08$ \\
\hline Tanzania & 640.76 & $2.7 \mathrm{E}+10$ & 26.72 & $1 \mathrm{E}+09$ & 102.59 & $4.5 \mathrm{E}+09$ & 266.16 & $1.16 \mathrm{E}+10$ & 188.69 & $8.17 \mathrm{E}+09$ \\
\hline Tunisia & 3622.42 & $3.8 \mathrm{E}+10$ & 0.00 & 0 & 987.20 & $1 \mathrm{E}+10$ & 1995.80 & $2.08 \mathrm{E}+10$ & 333.07 & $3.46 \mathrm{E}+09$ \\
\hline Uganda & 525.81 & $1.7 \mathrm{E}+10$ & 0.54 & $2 \mathrm{E}+07$ & 109.73 & $3.5 E+09$ & 241.42 & $7.72 E+09$ & 136.98 & $4.28 \mathrm{E}+09$ \\
\hline Zambia & 1244.30 & $1.6 \mathrm{E}+10$ & 5.96 & $9 \mathrm{E}+07$ & 367.64 & $4.9 \mathrm{E}+09$ & 628.24 & $8.38 \mathrm{E}+09$ & 142.09 & $1.78 \mathrm{E}+09$ \\
\hline Zimbabwe & 1088.73 & $1.5 \mathrm{E}+10$ & 40.26 & $5 \mathrm{E}+08$ & 155.06 & $2.1 \mathrm{E}+09$ & 468.97 & $6.47 \mathrm{E}+09$ & 130.94 & $1.72 \mathrm{E}+09$ \\
\hline
\end{tabular}




\subsection{Table 6a. Regression output of GDP on independent variables For Africa}

\begin{tabular}{|c|c|c|c|c|c|c|}
\hline Variable & Model 1 & Model 2 & Model 3 & Model 4 & Model 5 & Model 6 \\
\hline GOLD & $0.110 * * *(0.02)$ & $0.019 * *(0.05)$ & $0.008 * * *(0.00)$ & $0.005 * *(0.00)$ & $0.007(0.02)$ & $-0.004(0.02)$ \\
\hline INDUSTRY & & $0.214 * * *(0.04)$ & $0.092 * * *(0.02)$ & $0.089 * * *(0.02)$ & $0.24 * * *(0.05)$ & $0.220 * * *(0.05)$ \\
\hline SERVICES & & $0.367 * * *(0.05)$ & $0.121^{* *}(0.04)$ & $0.110^{* *}(0.04)$ & $-0.07(0.07)$ & $-0.056(0.07)$ \\
\hline AGRICULTURE & & $0.388 * * *(0.06)$ & $0.110 *(0.04)$ & $0.117^{* *}(0.04)$ & $0.161^{* *}(0.06)$ & $0.160 * *(0.06)$ \\
\hline GPDpc Lag1 & & & $0.671 * * *(0.08)$ & $0.648 * * *(0.06)$ & $0.662 * * *(0.07)$ & $0.641 * * *(0.06)$ \\
\hline \multicolumn{7}{|l|}{ Year effects } \\
\hline 1999 & & & & $-0.004(0.05)$ & & $-0.003(0.01)$ \\
\hline 2000 & & & & $-0.005(0.06)$ & & $-0.004(0.01)$ \\
\hline 2001 & & & & $0.014 *(0.00)$ & & $0.015 *(0.01)$ \\
\hline 2002 & & & & $0.016(0.01)$ & & $0.017 *(0.01)$ \\
\hline 2003 & & & & $0.002(0.01)$ & & $0.004(0.01)$ \\
\hline 2004 & & & & $0.023^{* *}(0.01)$ & & $0.023 * *(0.01)$ \\
\hline 2005 & & & & $0.027^{* *}(0.01)$ & & $0.027 * *(0.01)$ \\
\hline 2006 & & & & $0.031 * *(0.01)$ & & $0.030 * *(0.01)$ \\
\hline 2007 & & & & $0.032 * *(0.01)$ & & $0.031 * *(0.01)$ \\
\hline 2008 & & & & $0.030 *(0.01)$ & & $0.030 *(0.01)$ \\
\hline 2009 & & & & $0.018(0.01)$ & & $0.017(0.01)$ \\
\hline 2010 & & & & $0.044 * *(0.01)$ & & $0.042 * *(0.01)$ \\
\hline 2011 & & & & $0.039 * *(0.01)$ & & $0.037 *(0.01)$ \\
\hline 2012 & & & & $0.047^{* *}(0.02)$ & & $0.043^{* *}(0.02)$ \\
\hline 2013 & & & & $0.033(0.02)$ & & $0.031(0.02)$ \\
\hline 2014 & & & & $0.039 *(0.02)$ & & $0.037 *(0.02)$ \\
\hline 2015 & & & & $0.031(0.02)$ & & $0.030(0.02)$ \\
\hline 2016 & & & & $0.031(0.02)$ & & $0.031(0.02)$ \\
\hline \multicolumn{7}{|l|}{ Interactions } \\
\hline GOLD*INDUSTRY & & & & & $-0.008 * *(0.00)$ & $-0.007 *(0.00)$ \\
\hline GOLD *SERVICES & & & & & $0.01 * *(0.00)$ & $0.009 * *(0.00)$ \\
\hline GOLD*AGRICULTURE & & & & & $-0.003(0.00)$ & $-0.002(0.00)$ \\
\hline Observations & 920 & 920 & 874 & 874 & 874 & 874 \\
\hline Countries & 46 & 46 & 46 & 46 & 46 & 46 \\
\hline $\mathrm{F}(\mathrm{X}, \mathrm{X})$ & 36.93 & 1275.57 & 4085.92 & 1416.73 & 2498.25 & 1433.82 \\
\hline Prob $>F$ & 0.0000 & 0.0000 & 0.0000 & 0.0000 & 0.0000 & 0.0000 \\
\hline $\mathrm{R}^{\wedge} 2$ & 0.1772 & 0.9701 & 0.9975 & 0.9974 & 0.9981 & 0.9973 \\
\hline
\end{tabular}

Note: Significance levels - *** 99.9\%,**99\%,*95\%; Constant has been omitted from above table for all models; All models are OLS with fixed effects per country and robust standard errors; Data from 1999 to 2015. 


\subsection{Table 6b. Regression output of GDPpc on independent variables For Africa}

\begin{tabular}{|c|c|c|c|c|c|c|}
\hline Variable & Model 1 & Model 2 & Model 3 & Model 4 & Model 5 & Model 6 \\
\hline GOLD & $0.045^{* * *}(0.01)$ & $0.017 * * *(0.01)$ & $0.006^{* *}(0.00)$ & $0.004 *(0.00)$ & $-0.008(0.02)$ & $-0.018(0.02)$ \\
\hline INDUSTRY & & $0.219 * * *(0.04)$ & $0.092 * * *(0.02)$ & $0.090 * * *(0.02)$ & $0.104 * * *(0.02)$ & $0.102 * * *(0.02)$ \\
\hline SERVICES & & $0.379 * * *(0.05)$ & $0.128 * * *(0.03)$ & $0.113 * * *(0.03)$ & $0.120 * * *(0.03)$ & $0.107 * * *(0.03)$ \\
\hline AGRICULTURE & & $0.324 * * *(0.06)$ & $0.082 * *(0.03)$ & $0.096^{* * *}(0.03)$ & $0.083^{* *}(0.03)$ & $0.1^{* * *}(0.03)$ \\
\hline GPDpc Lag1 & & & $0.690 * * *(0.05)$ & $0.660 * * *(0.05)$ & $0.683 * * *(0.05)$ & $0.655^{* * *}(0.05)$ \\
\hline \multicolumn{7}{|l|}{ Year effects } \\
\hline 1999 & & & & $0.003(0.07)$ & & $0.001(0.07)$ \\
\hline 2000 & & & & $0.003(0.07)$ & & $0.003(0.07)$ \\
\hline 2001 & & & & $0.008(0.07)$ & & $0.008(0.07)$ \\
\hline 2002 & & & & $0.011(0.08)$ & & $0.012(0.09)$ \\
\hline 2003 & & & & $0.022(0.07)$ & & $0.007(0.08)$ \\
\hline 2004 & & & & $0.022 * *(0.01)$ & & $0.023 * * *(0.07)$ \\
\hline 2005 & & & & $0.025^{* *}(0.01)$ & & $0.028 * * *(0.08)$ \\
\hline 2006 & & & & $0.031 * * *(0.01)$ & & $0.033^{* * *}(0.07)$ \\
\hline 2007 & & & & $0.032 * * *(0.01)$ & & $0.033 * * *(0.08)$ \\
\hline 2008 & & & & $0.029 * *(0.01)$ & & $0.030 * * *(0.01)$ \\
\hline 2009 & & & & $0.014(0.01)$ & & $0.015(0.01)$ \\
\hline 2010 & & & & $0.039 * * *(0.01)$ & & $0.039 * * *(0.01)$ \\
\hline 2011 & & & & $0.033^{* * *}(0.01)$ & & $0.034 * * *(0.01)$ \\
\hline 2012 & & & & $0.041 * * *(0.01)$ & & $0.040 * * *(0.01)$ \\
\hline 2013 & & & & $0.030(0.01)$ & & $0.027 *(0.01)$ \\
\hline 2014 & & & & $0.030 * *(0.01)$ & & $0.030 * *(0.01)$ \\
\hline 2015 & & & & $0.023 *(0.01)$ & & $0.024 *(0.01)$ \\
\hline 2016 & & & & $0.025 *(0.01)$ & & $0.025 *(0.01)$ \\
\hline \multicolumn{7}{|l|}{ Interactions } \\
\hline GOLD*INDUSTRY & & & & & $-0.007 *(0.03)$ & $-0.006 *(0.00)$ \\
\hline GOLD *SERVICES & & & & & $0.008^{*}(0.00)$ & $0.008 *(0.00)$ \\
\hline GOLD*AGRICULTURE & & & & & $0.000(0.00)$ & $0.002(0.00)$ \\
\hline Observations & 920 & 920 & 874 & 874 & 874 & 874 \\
\hline Countries & 46 & 46 & 46 & 46 & 46 & 46 \\
\hline $\mathrm{F}(\mathrm{X}, \mathrm{X})$ & 16.59 & 204.02 & 1685.57 & 596.82 & 1226.56 & 707.29 \\
\hline Prob $>$ F & 0.0002 & 0 & 0 & 0 & 0 & 0 \\
\hline $\mathrm{R}^{\wedge} 2$ & 0.0477 & 0.9721 & 0.9975 & 0.9972 & 0.9976 & 0.9973 \\
\hline
\end{tabular}

Note: Significance levels - *** 99.9\%,**99\%,*95\%; Constant has been omitted from above table for all models; All models are OLS with fixed effects per country and robust standard errors; Data from 1999 to 2015. 


\subsection{Table 7a. Regression output of GDP on independent variables For Ghana}

\begin{tabular}{lllll}
\hline Variable & Model 1 & Model 2 & Model 3 & Model 5 \\
\hline GOLD & $0.75^{* * *}(0.09)$ & $0.125^{* *}(0.04)$ & $0.082^{*}(0.03)$ & $1.73(1.60)$ \\
INDUSTRY & & $0.208^{* * *}(0.02)$ & $0.090^{*}(0.033)$ & $0.81^{* *}(0.26)$ \\
SERVICES & & $0.346^{* * *}(0.02)$ & $0.177^{* * *}(0.04)$ & $-0.07(0.12)$ \\
AGRICULTURE & & $0.327^{* * *}(0.07)$ & $0.137^{* *}(0.04)$ & $1.12(1.25)$ \\
GPDpc Lag1 & & $0.527^{* * *}(0.12)$ & $0.343^{* * *}(0.13)$ \\
Interactions & & & & \\
GOLD*INDUSTRY & & & & $-0.144^{* *}(0.05)$ \\
GOLD *SERVICES & & & & $0.05^{* *}(0.02)$ \\
GOLD*AGRICULTURE & & & 19 & $-0.205(0.26)$ \\
& & & 8273.69 & 19 \\
Observations & 20 & 20 & 0 & 1973 \\
$\mathrm{~F}(\mathrm{X}, \mathrm{X})$ & 68.96 & 2344.5 & 0.999 & 0.9987 \\
Prob> F & 0 & 0 & & \\
$\mathrm{R}$ (2 & 0.411 & 0.9963 & & \\
\hline
\end{tabular}

Note: Significance levels - *** 99.9\%,** 99\%,* 95\%; Constant has been omitted from above table for all models; All models are OLS with robust standard errors; Data from 1997 to 2016. 


\subsection{Table7b. Regression output of GDPpc on independent variables}

For Ghana

\begin{tabular}{lllll}
\hline Variable & Model 1 & Model 2 & Model 3 & Model 5 \\
\hline GOLD & $0.18(0.18)$ & $0.128^{* *}(0.03)$ & $0.082^{*}(0.03)$ & $2.309(3.87)$ \\
INDUSTRY & & $0.206^{* * *}(0.01)$ & $0.089^{*}(0.03)$ & $3.040 *(1.12)$ \\
SERVICES & & $0.346^{* * *}(0.02)$ & $0.177^{* * *}(0.04)$ & $-0.855(0.17)$ \\
AGRICULTURE & & $0.276^{* * *}(0.06)$ & $0.135^{* *}(0.04)$ & $0.496(4.68)$ \\
GPDpc Lag1 & & $0.537 * *(0.13)$ & $0.402(0.10)$ \\
Interactions & & & $-0.134 *(0.05)$ \\
GOLD*INDUSTRY & & & & $0.049(0.06)$ \\
GOLD *SERVICES & & & & $-0.017(0.22)$ \\
GOLD*AGRICULTURE & & & 19 & 19 \\
& & & 2999.94 & 3063.42 \\
Observations & 20 & 20 & 0 & 0 \\
F(X,X) & 0.98 & 781.01 & 0.9971 & 0.9973 \\
Prob> F & 0.3356 & 0 & & \\
R^2 & 0.0394 & 0.9896 & & \\
\hline
\end{tabular}

Note: Significance levels - *** 99.9\%, ** 99\%,* 95\%; Constant has been omitted from above table for all models; All models are OLS with robust standard errors; Data from 1997 to 2016. 


\section{Copyright documentation}

Images in this paper are from Google. They are all public domain, or licensed for reuse under Creative Commons license 3.0. below are full citation and acknowledgement information.

Minerals Deposit (Belts) Map of Ghana. Image source: Google maps, available at https://www.google.com/search?q=Map+Regions+with+gold+deposits+in+Ghana - . Accessed May 2019.

Map Regions with gold deposits in Ghana. Image source: Google maps available at https://www.google.com/search?q=Map+Regions+with+gold+deposits+in+Ghana. Accessed May 2019. 